2020-04-15

\title{
Impact of a headland-associated sandbank on shoreline dynamics
}

McCarroll, Jak

http://hdl.handle.net/10026.1/15454

10.1016/j.geomorph.2020.107065

Geomorphology

Elsevier BV

All content in PEARL is protected by copyright law. Author manuscripts are made available in accordance with publisher policies. Please cite only the published version using the details provided on the item record or document. In the absence of an open licence (e.g. Creative Commons), permissions for further reuse of content should be sought from the publisher or author. 


\title{
Impact of a headland-associated sandbank on shoreline dynamics
}

\author{
R. Jak McCarroll ${ }^{1}$, Gerd Masselink ${ }^{1}$, Nieves G. Valiente $^{1}$, Mark Wiggins ${ }^{1}$, \\ Tim Scott ${ }^{1}$, Daniel Conley ${ }^{1}$ \& Erin V. King ${ }^{1}$ \\ ${ }^{1}$ School of Biological and Marine Sciences, Plymouth University, Drake Circus, PL4 8AA, Plymouth, UK \\ Corresponding author: R. Jak McCarroll (jak.mccarroll@plymouth.ac.uk)
}

This is the author's accepted manuscript. The final published version of this work (the version of record) is published by Elsevier in Geomorphology, Feb 2020, available at:

https://doi.org/10.1016/i.geomorph.2020.107065 . This work is made available in accordance with the publisher's policies. Please refer to any applicable terms of use of the publisher.

\section{Highlights}

- First robust study of bank control on inshore waves and longshore transport.

- $20 \%$ change to bank elevation $(\leq 5 \mathrm{~m})$ significantly impacts longshore flux.

- Directly in lee of bank, shoreline flux is a continuous function of bank depth.

- Bank protects shore, dissipating direct waves and refracting away oblique waves.

- Raised bank would substantially accrete distal $(>5 \mathrm{~km})$ currently eroding shoreline.

\section{Key words}

Banner bank, gravel beach, longshore sediment transport, aggregate dredging, decadal shoreline change. 


\begin{abstract}
Sandbanks can occur downdrift of headlands across embayments as a result of tidal currents and wave forcing, and can present a potentially valuable resource of marine aggregate material. Large sandbanks can alter tidal flows and, through refraction and dissipation, increase or decrease wave exposure along the shoreline of an embayment. The impact of offshore sandbanks on shoreline morphodynamics at varying timescales has not been rigorously investigated. Here we show, for the first time, that removing, lowering or raising a headland-associated sandbank can have a significant impact on longshore sediment transport. A Delft3D model of Start Bay and Skerries Bank, UK, validated on hydrodynamic observations, was used to conduct the numerical experiments. Results indicate that removing or lowering the bank generally reduces dissipation and increases wave heights, increasing longshore flux in the lee of the bank. Raising the bank generally has the opposite effect, increasing dissipation and lowering flux. Under oblique waves, the bank may protect the adjacent shoreline by refracting waves away from the coast. Shoreline flux for the region directly onshore of the bank acts as a continuous function of bank height $\left(R^{2}=0.7\right)$, but correlations for distal regions are increasingly non-linear or absent. A raised bank would reduce transport rates to near-zero across extensive sections of the bay, reversing the long-term net flux at points distal ( $>5 \mathrm{~km}$ from bank) from the bank location, causing currently eroding regions to accrete. Our results demonstrate that moderate $(\leq 5 \mathrm{~m})$ elevation changes to a sandbank will likely produce significant variations in wave power at the shoreline, which will: (i) modify the shoreline response for individual storms; and (ii) substantially change shoreline morphology at decadal timescales. From a broader perspective, this study can be used to inform planning decisions involving naturally varying banks and/or potential mining of sandbanks, aiding shoreline protection strategies for locations with similar embayment-sandbank configurations.
\end{abstract}




\section{Introduction}

Sandbanks are sediment bodies that can be found in regions of plentiful sand supply, typically where residual tidal currents converge to create and maintain the bank (Dyer and Huntley, 1999). Sandbanks are of interest in regard to the morphodynamic processes that form and maintain them (e.g., Roos et al, 2004; Berthot and Pattiaratchi, 2006b), while also providing a resource for marine aggregate extraction (e.g., Hitchcock et al., 2004; Van Lancker et al., 2010). Additionally, sandbanks may provide protection or increased wave exposure to shorelines adjacent to the bank due to their influence on dissipation and refraction processes (Coughlan et al., 2007; Dolphin et al., 2007).

'Headland-associated' sandbanks or 'banner banks' (Dyer and Huntley, 1999) are a sub-type of sandbank, most common in meso-macrotidal environments, that can be found on one or both sides of a headland where strong tidal currents occur, with wave action also impacting sandbank dynamics in some settings (Guillou and Chapalain, 2011; Schmitt and Mitchell, 2014; Fairley et al., 2016). The primary mechanism for headland-associated sandbank formation is a convergence in residual flow adjacent to the headland (Bastos et al., 2004; Berthot and Pattiaratchi, 2006a,b). In this scenario, flow diverges and forms an eddy as it passes the headland (Pingree, 1978; Dyer and Huntley, 1999), then converges toward the headland on the alternate stage of the tide. The resultant flow features a zone of convergence where the residual current velocities approach zero in the region of the crest of the bank. Banks are likely to be near-circular when initiated, becoming elongate over time as they interact with and modify tidal currents (Berthot and Pattiaratchi, 2006b). Three-dimensional secondary flow, which is the balance between the centrifugal force and pressure gradient, is also important for headland-associated sandbank formation (Pingree, 1978; Bastos et al., 2004; Berthot and Pattiaratchi, $2006 a, b)$, as vortical currents circulate around sandbanks.

Dredging of sandbanks as a source of marine aggregate material is a global industry (Van Lancker et al., 2010), with examples of operations in the UK (Hitchcock and Bell, 2004), Europe (Briere et al., 
2010) and North America (Drucker et al., 2004). Investigations into dredging impacts have focussed on instantaneous effects, such as sediment-plume dispersal (e.g., Hitchcock and Bell, 2004; RomanSierra et al., 2011) and long-term impacts on bank morphology (e.g., Briere et al., 2010). For some cases, it has been concluded that the impact is likely to be localised to the site of the dredging (Degrendele et al., 2010). In other instances, sandbanks have been found to significantly decrease in volume over time (Lewis et al., 2014) due to a combination of dredging and wave-induced erosion, potentially altering wave-dynamics over the bank. In contrast to the dynamics of the banks themselves, little information exists on the controls that offshore sandbanks exert on adjacent coastlines. The potential impacts of dredging on inshore waves and shoreline dynamics are commonly modelled as a precautionary measure before commencing a dredging project (Drucker et al., 2004); yet, these outputs are typically not made available in the literature and no effort has been made to robustly investigate the processes involved.

A handful of sites have been studied with regard to the natural variability of tidal sandbank morphology and how this may impact on nearby coastlines. The Newcombe Sands bank (Lowestoft, UK; Dolphin et al., 2007) is associated with soft headlands or 'nesses' and was determined to evolve through two distinct morphological states (linear and deltaic lobes) at multi-decadal timescales. During times of high-bank elevation, shoreline erosion onshore of the bank was counterintuitively more extreme (Dolphin et al., 2007). Initial numerical modelling of Newcombe Sands (Coughlan et al., 2007) found that varying the tidal stage over the present-day bathymetry could alter longshore transport rates by up to an order of magnitude. On the same coastline (south-eastern UK), Robinson (1980) identified that 'sediment bridges' between sandbanks and the shoreline could act to supply sand to nesses, while a gradually growing sandbank could act to protect the coast from erosion. Another site of interest comprises the open-coast tidal-sandbanks off Calais, France (Hequette et al., 2010), which were found to weld to the coast at multi-decadal timescales, producing substantial 
progradation. A short-term field experiment measuring currents on the same coastline (Hequette et al., 2009) found that the shoreline onshore of a sandbank was more exposed to erosion than neighbouring shorelines, due to increased currents between the shoreline and the bank. A single observational study has examined the impact of aggregate extraction on coastal erosion, using a limited set a field data (Phillips, 2008), finding no link between dredging and shoreline change. No attempt has yet been made to investigate the potential impact of a headland-associated sandbank on shoreline dynamics across the extent of the associated embayment.

Our objective is to take a well-studied exemplar of a headland-associated 'banner bank' (Skerries Bank in Start Bay, UK; Dyer and Huntley, 1999) and use this setting to conduct the first numerical experiment that examines the impact of a sandbank on shoreline dynamics, over a variety of temporal scales. The focus is on variations in alongshore transport, the dominant control in this environment (Wiggins et al., 2019a). The hypothesis is that changes to the elevation of the bank (both lowering and raising the crest), will modify wave propagation by altering dissipation and refraction, thereby causing significant changes to longshore transport rates at the shoreline. Section 2 introduces the site and describes trends in longshore flux, Section 3 describes the methods and Section 4 outlines the validation of a Delft3D coupled WAVE-FLOW model. Section 5 provides the results including modelling of bi-modal storm directions across the various bathymetries for Skerries Bank (real bathymetry, total removal, lowering, and raising of the bank), estimating cumulative longshore transport. Section 6 extends the results to introduce a simplified look-up/interpolation approach to predict decadal-scale impacts. Sections 7 and 8 are the discussion and conclusions.

\section{Site description}

Start Bay is a 12-km long, embayed gravel barrier system located in South Devon, along the south coast of England, UK (Fig. 1a). Comprised of five inter-connected beaches (Hallsands, Beesands, 
Slapton Sands, Forest Cove and Blackpool Sands), shoreline sediment is comprised mainly of rounded gravel $\left(D_{50}=2-10 \mathrm{~mm}\right)$ derived from flint and quartz, with some locally sourced material in the form of mica-schist and slate resulting from cliff erosion (Ruiz de Alegria-Arzaburu and Masselink, 2010). Freshwater lagoons lie behind both Slapton Sands and Beesands, with smaller rivers and marshes at Hallsands and Blackpool Sands. The present barrier positions are thought to be the result of a landward transgression of sediment during sea-level rise in the mid-Holocene period (Hails, 1975a). The initial formation of barrier islands and tidal inlets eventually completely enclosed the lagoons and the beach position has remained relatively stable for the last 3000 years. The current barrier at Slapton rises to approximately 5-6 $\mathrm{m}$ above mean sea level (Kelland, 1975), with a steep beach face $(\tan \beta=$ 0.125), and beach toe elevation of -8 to $-10 \mathrm{~m}$ Ordnance Data Newlyn (ODN; mean sea level is $\sim 0.4 \mathrm{~m}$ ODN in 2018). Lateral grading of beach material results in smaller particles being sorted and transported north under dominant southwesterly wave directions, whilst coarser grains move southward under high energy easterly wave events (Chadwick et al., 2005). The embayment is mesoto macro-tidal, with a range of $1.8 \mathrm{~m}$ for neaps and $4.3 \mathrm{~m}$ for springs. Tidal currents create a circular system of northward flow offshore during flood tides and southwesterly flows inshore during the ebb (Dyer and Huntley, 1999).

Orientated from the SSW to NNE, the embayment faces southeast into the English Channel and receives a directionally bi-modal wave climate (Fig. 1b,c). Predominant southwesterly Atlantic swell waves refract into the bay, resulting in the majority of inshore waves being southerly (Fig. 1C), whilst less frequent, easterly wind waves generally maintain their original angle (Ruiz de Alegria-Arzaburu and Masselink, 2010). Both southerly and easterly wave directions are oblique to the shoreline and can drive significant longshore sediment transport, resulting in rotation of individual beaches, and in extreme cases the full embayment (Masselink et al., 2016, Scott et al., 2016, Wiggins et al., 2019a, McCarroll et al., 2019a), at event to multi-annual timescales. Changes to the balance of the wave 
climate over longer periods (decadal) has been shown to control the beach morphology at opposing ends of the embayment (Wiggins et al 2019a,b). Variation in alongshore transport is the dominant control on shoreline change (McCarroll et al., 2019a; Wiggins et al., 2019a), and is the primary focus of this work. Cross-shore transport is secondary (McCarroll et al., 2019b) and is not addressed in detail.
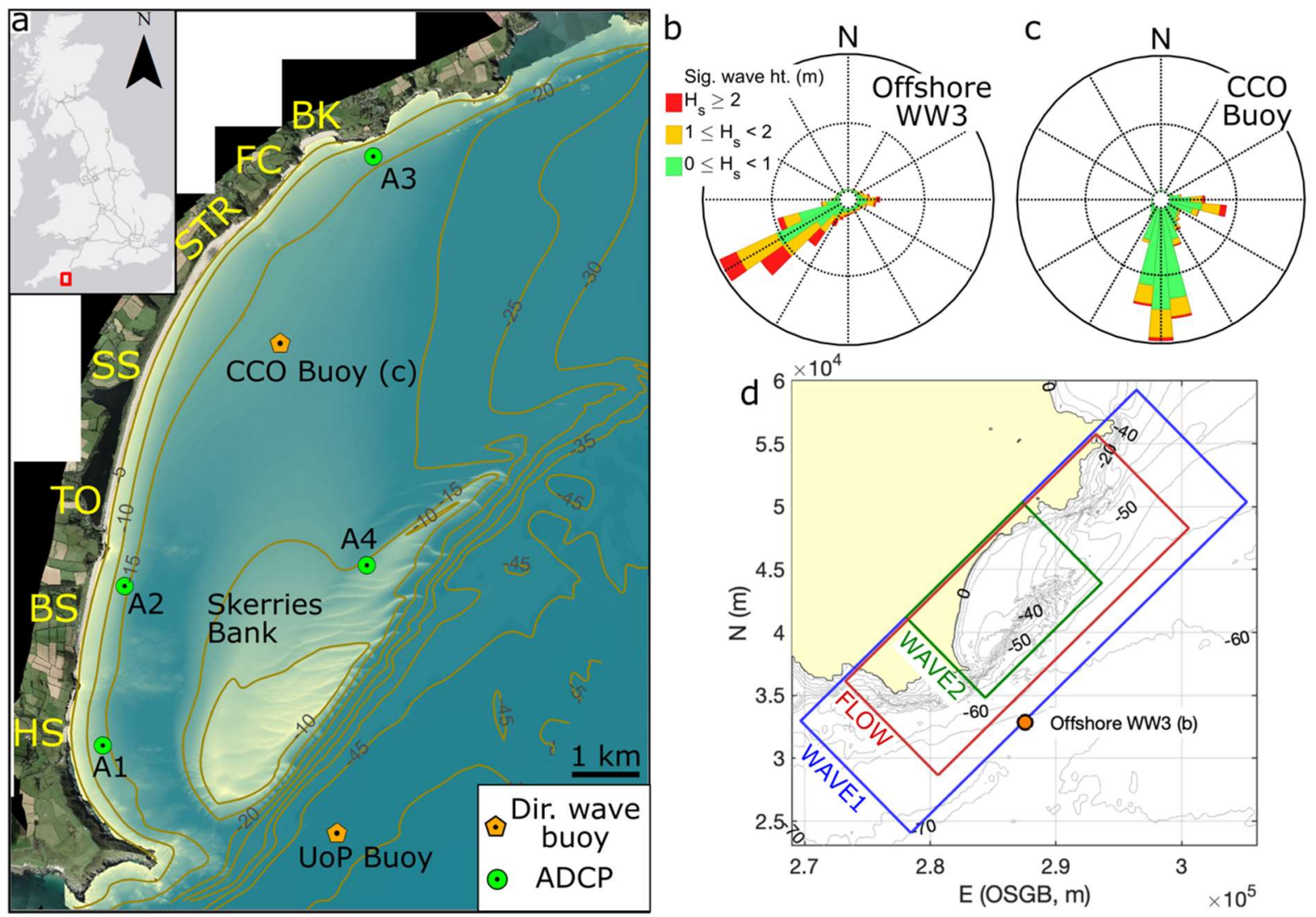

Figure 1. Start Bay and Skerries Bank, including: (a) site map; (b) wave rose for Met Office WW3 node located 6

km offshore of Start Point for 1980 to 2018; (c) wave rose of CCO Buoy for 2007 to 2018; and (d) Delft3D model grids, location of example WW3 node indicated. Locations in (a) referred to throughout the text include: Hallsands beach (HS); Beesands beach (BS); Torcross-Slapton Sands-Strete beach (TO-SS-STR); Forest Cove (FC); and Blackpool Sands beach (BK).

To the east of Start Bay lies Skerries Bank (Fig. 1a), an offshore banner bank approximately 2-4 km from the shoreline, orientated in a similar direction to the main embayment planform. Situated on the sloping shelf in the central to southern half of the embayment in depths of -11 to $-15 \mathrm{~m}$ ODN, its 
crest is approximately $-7 \mathrm{~m}$ ODN. The bank acts to refract passing waves, and during low tides, larger waves may shoal and break over the bank (Holmes 1975a, 1975b). To the south, Skerries is separated from the main headland, Start Point, by a deeper channel which experiences strong southeasterly tidal flows, particularly during the ebb tide (Acton and Dyer, 1975). The bank is comprised entirely of coarse shelly sands (Hails, 1975b), formed by tidal currents and wave action. Skerries overlays finer silts and sands, suggesting that sediment exchanges with the main beaches of Start Bay, which consist predominantly of flint pebbles, are limited (Hails, 1975b). Previous work by Robinson (1961) concluded that the planform and morphology of Skerries has been relatively stable since the early $19^{\text {th }}$ century, with only little change at the extremities measured from 1825 to 1951 . There is, however, evidence of sediment transport on the crest of the bank (Robinson, 1961), with tidal current velocities being high enough to move material, as well as wave breaking and potential entrainment of finer particles (Acton and Dyer, 1975). Ultimately, Robinson (1961) concluded that the circulatory, tide-driven currents around the bank effectively maintain the outer limits by transporting material southward and eastward under more dominant ebb currents, also preventing exchanges between the bank, bay and barrier sediment systems.

The village of Hallsands, in the southwest corner of Start Bay, experienced dredging of beach material from the subtidal bed directly in front of the village between 1897 and 1902 . Estimates of total volumes extracted vary from $300,000 \mathrm{~m}^{3}$, to up to 1.8 million $\mathrm{m}^{3}$ (May and Hansom, 2003). This loss of beachface substrate was potentially a factor in shoreline retreat of up to $30 \mathrm{~m}$, increased wave damage to sea walls, and ultimately, the loss of the village to storms in 1917 (Hails, 1975a; Wiggins et al., 2017). There is still debate over whether the Skerries Bank was also used as a site for dredging. Anecdotal tales of village cricket matches played on the Skerries at low tides suggest that the bank was once several meters higher than present. Letters from the Board of Trade revoking the dredging licence were made to the contractor, suggesting that Skerries was indeed mined, though estimates of 
volumes removed are not available. Hails and Carr (1975) provided a simple refraction model suggesting that Skerries Bank focusses wave energy from northeasterly directions onto the area of the bay around Hallsands, potentially adding to erosion at that site; however, a robust investigation of the impact of the bank on shoreline dynamics has not been conducted.

\section{Methods}

\subsection{Survey data and experimental bathymetries}

Topography along the shoreline of Start Bay was surveyed using an unmanned aerial vehicle (UAV) at 1-m resolution with a vertical uncertainty of $0.04 \mathrm{~m}$ (Wiggins et al., 2019a). High-resolution (1-m) multibeam bathymetry, with vertical uncertainty $<0.3 \mathrm{~m}$ (Wiggins et al., 2019a), was obtained along the shoreline of Start Bay to a depth of -10 m ODN by the University of Plymouth (UoP; 2017) and for the outer embayment, including Skerries Bank, by the United Kingdom Hydrographic Office (UKHO, 2013). These data were combined and linearly interpolated to a 50-m resolution digital elevation model, which is a sufficiently high resolution to capture changes in shoreline orientation at the scale of 100 's $\mathrm{m}$ to $\mathrm{km}$ 's.

In addition to the 'present' or control bathymetry (Fig. 2a; $B 1_{\text {present }}$ ), three test case bathymetries were generated, including: (i) a complete 'removal' of the Skerries Bank [Fig. 2b; B2 remove]; (ii) a $5 \mathrm{~m}$ lowering of the bank [Fig. 2c; $B 3_{\text {low }}$ ]; and (iii) a $\sim 5 \mathrm{~m}$ raising of the bank [Fig. $2 \mathrm{~d} ; \mathrm{B}_{\text {high }}$ ]. Note that a 5 m elevation change represents $\sim 20 \%$ of the bank elevation at the crest (Fig. $2 \mathrm{~d}$ ). The $B 2_{\text {remove }}$ scenario was generated by deleting bathymetry around Skerries, manually drawing in contour lines that approximately follow the orientation of a buried relict coastline (Hails, 1975a), and then linearly interpolating across the regions around the drawn contours. $B 2_{\text {remove }}$ (Fig. $2 \mathrm{~b}$ ) is intended to test the most extreme case for shoreline impact and represents an alternative evolution of Start Bay, for example with limited offshore sediment supply. $B 3_{\text {low }}$ was generated by lowering the region around 
the crest of Skerries Bank (Fig. $2 \mathrm{c}$ ) to $\mathrm{z}=-12 \mathrm{~m}$ ODN, involving a lowering of $\sim 5 \mathrm{~m}$ from the crest. $B 3_{\text {low }}$ is intended to represent a scenario where mining has occurred, or natural processes have eroded the bank, with the reduction in volume being on the order of $10^{7} \mathrm{~m}^{3} . B 4_{\text {high }}$ was generated by adding a concave down hemi-ellipsoid with a flattened top to the region over the crest, such that crest is raised by a maximum of $5 \mathrm{~m}$ (Fig. $2 \mathrm{~d}$ ), tapering to zero at boundary of the ellipse. $B 4_{\text {high }}$ represents a past or future scenario where the bank has attained or will attain a higher elevation due to natural processes or anthropogenic impacts. 

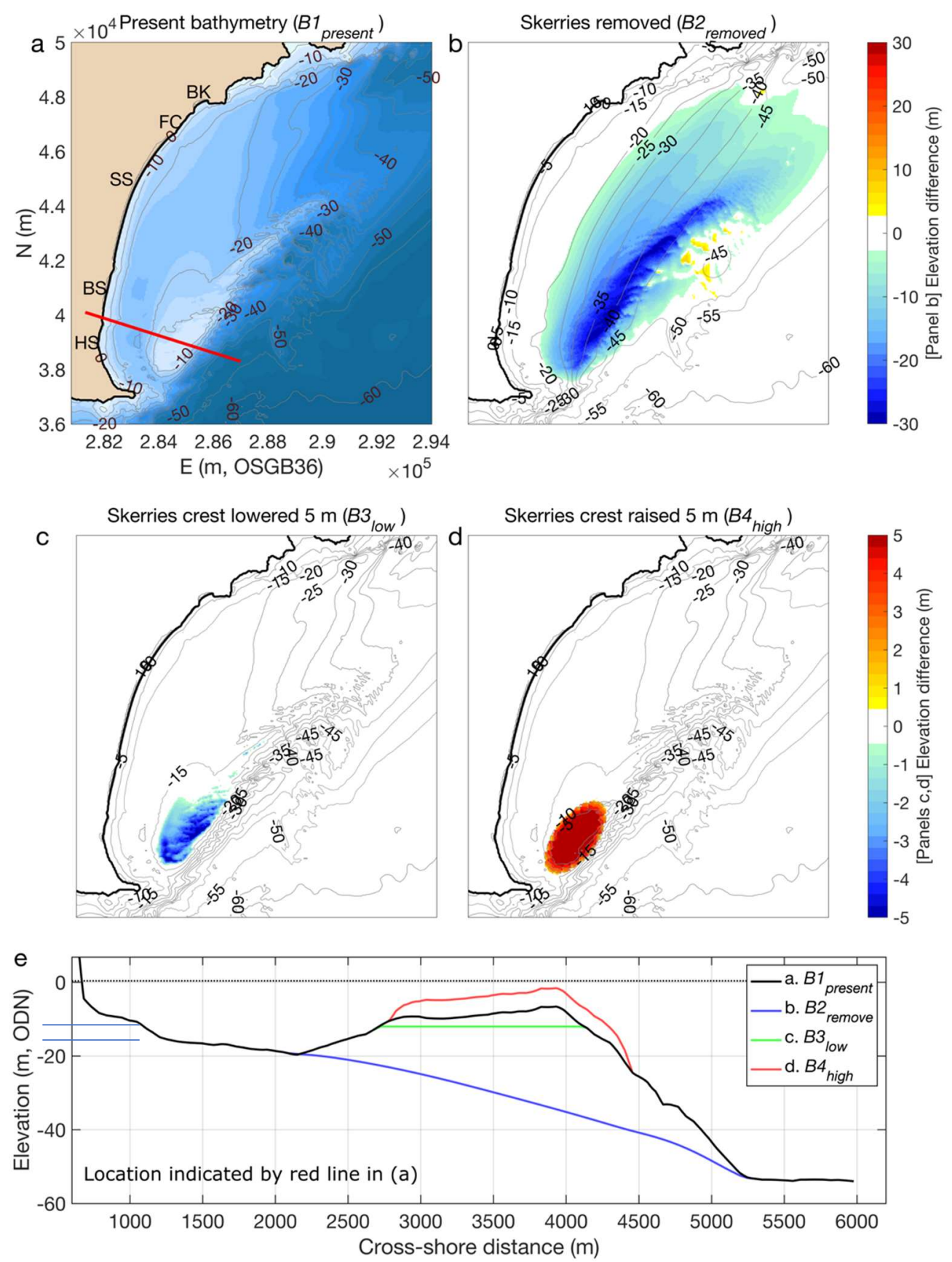

Figure 2. Start Bay and Skerries Bank bathymetries used for modelling simulations, including: $\left(a, B 1_{\text {present }}\right)$ the reference case 'present' bathymetry, red line indicates profile location; (b, B2removed) the first test case with Skerries Bank 'removed' entirely; ( $c, B 3$ low $)$ the second test case with Skerries lowered by a maximum of $5 \mathrm{~m}$; (d, B4high) the third test case with Skerries raised by up to $5 \mathrm{~m}$; and (e) cross-shore profiles across the Skerries crest for all four bathymetries. Dotted line is mean sea level. Colormaps in (b-d; note the differing scales) show the bed level difference between the reference case (a) and the test cases. 


\subsection{Hydrodynamic observations}

Directional wave observations were obtained from the Channel Coastal Observatory wave buoy at a depth of -16 m ODN (Fig. 1b; CCO Buoy) for the period 2007-2018, at 1-h intervals. Hydrodynamic observations across Start Bay were collected as part of a larger field experiment conducted by the University of Plymouth over the period 24 Jan to 11 Apr 2018. These include wave and current measurements from Acoustic Doppler Current Profilers (ADCP, 600/1200 kHz RDI Workhorse) and a directional wave buoy (UoP Buoy) located off Start Point (Fig. 1a). The ADCPs were all situated at -14 m ODN, with 0.5-m bin spacing, collecting ensemble-sampled current data at 5-min intervals and wave data with 20-min burst samples at 1-h intervals. ADCP current data were low-pass filtered with a 30min Fourier transform filter to remove spikes. The UoP Buoy was situated in $\sim 55 \mathrm{~m}$ water depth, sampling hourly wave data.

\subsection{Numerical model and scenarios}

A depth-averaged (2D-horizontal) Delft3D model (Lesser et al., 2004) was developed, with onlinecoupling of the WAVE and FLOW modules, including wind forcing. The model domain includes Start Bay, Skerries Bank and the surrounding coastline and is comprised of three rectilinear grids (Fig. 1c), including: (i) an outer-WAVE grid [500-m resolution]; (ii) a FLOW grid [100-m]; and (iii) an inner-WAVE grid [100-m]. This resolution is sufficient to capture the variations in morphology over Skerries Bank ( $\sim \mathrm{km}$ long by up to $2 \mathrm{~km}$ wide) and gradual variations along the Start Bay shoreline ( $12 \mathrm{~km}$ long). A higher resolution would be required to capture the dynamics of bypassing at the various headlands along the embayment; however, we do not attempt to resolve bypassing rates in this study. The WAVE model boundary was driven by input from an 8-km resolution Wave Watch III model (WW3; Tolman 1991) provided by the UK Met Office. Water level and current velocity boundary conditions for the FLOW model were obtained from the Forecasting Ocean Assimilation Model 7-km Atlantic Margin model (FOAM-AMM7; O'Dea et al., 2012). The $0.25^{\circ}$ IFREMER CERSAT global surface wind climatology 
model was used for wind forcing input. Both the WAVE and FLOW models were forced with a uniform wind field. Sediment transport and bed updating were switched off as Delft3D is unsuitable for modelling gravel transport. The numerical model was run for a 1-month calibration period and a 1month validation period. In addition, eight test-scenarios were executed, which are the total combinations between the two extreme storm sequences (including easterly storm Emma in Mar 2018 and southwesterly storm Petra in 2014) and the four experimental bathymetries ( $B 1_{\text {present }}, B 2_{\text {remove, }}$ $B 3_{\text {low }}$ and $\left.B 4_{\text {high }}\right)$.

\subsection{Alongshore sediment transport analysis}

Delft3D and other present generation hydro-morphodynamic models are unable to model 2Dhorizontal transport of gravel-sized sediment. An effective alternative technique for predicting alongshore sediment transport in gravel environments (e.g., Bergillos et al., 2017) is to model the nearshore wave height (outside the surfzone), then to transform the nearshore wave condition to the breakpoint, and finally to apply a longshore transport formulation (e.g., CERC; USACE 2002). This approach was previously applied to Start Bay (McCarroll et al., 2019a) and we take a similar approach here.

For the nearshore wave condition, the output from the WAVE model is extracted along the $-14 \mathrm{~m}$ ODN contour at 100-m intervals. The wave output parameters are then transformed to the breakpoint using the approach of Van Rijn (2014), to determine breaking depth:

$$
h_{b}[m]=\left[\left(H_{s, o}^{2} c_{o} \cos \theta_{o}\right) /\left(a \gamma_{\text {shore }}^{2} g^{0.5}\right)\right]^{0.4}
$$

and breaking wave angle relative to the shoreline:

$$
\sin \theta_{b}=\left(c_{b} / c_{o}\right) \sin \theta_{o}
$$

where subscripts ' $O$ ' indicates offshore and ' $b$ ' is at the breakpoint, $h$ is depth, $H_{s}$ is significant wave height, $c$ is wave propagation speed, $g$ is gravity and $a=1.8$, a calibration coefficient. The breaking 
coefficient $\left(\gamma_{s h o r}=H_{s, b} / h_{b}\right)$ is used to determine breaking wave height at the shoreline, here using $\gamma_{\text {shore }}=0.7$, a suitable value for the gravel beaches in Start Bay (McCarroll et al., 2019a). Alongshore wave power at the shoreline is determined using linear wave theory:

$$
P_{y}\left[N s^{-1}\right]=\frac{\rho g^{1.5}}{16 \sqrt{\gamma_{\text {shore }}}} H_{s, b}^{2.5} \sin \left(2 \theta_{b}\right)
$$

then the CERC equation (USACE, 2002) is applied to estimate longshore sediment volume flux:

$$
Q\left[m^{3} s^{-1}\right]=\frac{1}{\left(\rho_{s}-\rho\right) g(1-p)} K P_{y}
$$

Where $\rho_{s}$ is the density of the sediment $\left(2650 \mathrm{~kg} \mathrm{~m}^{-3}\right), \rho$ is the density of sea-water $\left(1025 \mathrm{~kg} \mathrm{~m}^{-3}\right)$ and $p$ is sediment pore space (0.4). $K$ is a transport rate coefficient that may vary with sediment size. $K=$ 0.04 is a recommended value for gravel (Van Rijn, 2014); however, an observed transport rate of $K=$ 0.26 was made for the Slapton Sands embayment in Start Bay across the Storm Emma sequence (McCarroll et al., 2019a). The high value for $K$ is used when simulating extreme storm conditions and, to account for uncertainty, we use a range of $K$-values for long-term predictions (section 3.6). This method was applied to each of the eight test-scenarios (four bathymetries and two storm directions).

\subsection{Look-up model and decadal transport rates}

Long-term (years to decades) numerical modelling simulations are computationally non-viable using a process-based model such as Delft3D. As an alternative, we introduce a transform function that is similar in approach to a look-up table, which also employs interpolation between simulated wave cases. First, Delft3D was run in stationary mode for a large array of scenarios ( $\sim 400)$ to encompass observed conditions. Variables included offshore wave height at the model boundary $\left(H_{s, \text { bnd }}=0.5 \mathrm{~m}\right.$ to $7.5 \mathrm{~m}$, at $0.5-\mathrm{m}$ intervals), peak period ( $T_{p, \text { bnd }}=5 \mathrm{~s}$ to $14 \mathrm{~s}$, at $3-\mathrm{s}$ intervals, capping values above 14 s) and wave direction ( $\theta_{\text {bnd }}=70^{\circ}$ to $110^{\circ}$ and $150^{\circ}$ to $270^{\circ}$, at $10^{\circ}$ intervals). The results were then linearly interpolated across this 3 -dimensional parameter space $\left(H_{s}, T p, \theta\right)$ by comparing the boundary conditions from the Met Office WW3 model (section 3.4) for a point on the SE boundary, to any point 
within the model domain for a given time-point, using the Matlab functions ndgrid and interpn. For example, for wave height at a given point $(x, y)$ within the domain:

$$
H_{s(x, y)}=f\left(H_{s, b n d}, T_{p, b n d}, \theta_{b n d}\right)
$$

To account for the absence of wind and the use of a spatially uniform boundary condition, coefficients were applied to correct the wave height and direction (see section 6). We also tested the inclusion of water level as an additional dimension, but it provided no extra skill. This implies that use of a static mean water level is approximately equivalent to averaging instantaneous values across tidal cycles, and was deemed suitable for an indicative estimate of long-term longshore sediment flux. Using this method, interpolated wave heights were determined along the -14 m contour, which were then used to calculate longshore transport rates using [1-4]. This method was applied to a 38.5-year dataset of wave boundary conditions obtained from the Met Office WWIII model (section 3.4) for the period 1980-2018 to estimate cumulative longshore transport rates for each of the four test bathymetries (section 3.1).

\section{Numerical model calibration}

The Delft3D model was calibrated over a 1-month period during which the ADCPs and UoP Buoy were deployed (10 Feb - 11 Mar 2018), including the easterly extreme storm sequence 'Emma' (Fig. 3a-c), and was validated for a subsequent 1-month period (12 Mar - $10 \mathrm{Apr} 2018$ ). The model was also validated against an extreme southerly storm sequence ('Petra', Fig. 3d-f). Characteristics of each storm sequence are given in Table 1. Model skill values are provided using the coefficient of determination $\left(R^{2}\right)$, mean absolute error $(M A E)$ and BIAS. This is a similar approach to Vieira da Silva et al. (2016) for a comparable Delft3D model. MAE is calculated as:

$$
M A E=\frac{1}{n} \sum\left|x_{\text {model, } t}-x_{\text {observation }, t}\right|
$$

where vertical lines indicate an absolute value, $x$ are the observed and modelled values at time-point $t$, and $n$ is the number of observations. BIAS is as per (Eq. 6), without taking the absolute value. 
Table 1: Storm characteristics, observed at the CCO Buoy.

\begin{tabular}{ll|cc} 
Storm sequence & Emma (E) & Petra (S) \\
\hline Start date & $12 \mathrm{pm}, 21 / 01 / 2018$ & $12 \mathrm{am}, 01 / 02 / 2014$ \\
End date & $12 \mathrm{am}, 03 / 03 / 2018$ & $12 \mathrm{am}, 08 / 02 / 2014$ \\
Duration & 9.5 days & 7 days \\
Wave height $\left(\boldsymbol{H}_{\mathrm{s}, 0}\right)$ & Max. & $5.6 \mathrm{~m}$ & $4.7 \mathrm{~m}$ \\
& Mean & $2.3 \mathrm{~m}$ & $1.9 \mathrm{~m}$ \\
Peak period & Mean & $7.4 \mathrm{~s}$ & $10.5 \mathrm{~s}$ \\
Wave direction & Mean & $98^{\circ}$ & $172^{\circ}$
\end{tabular}
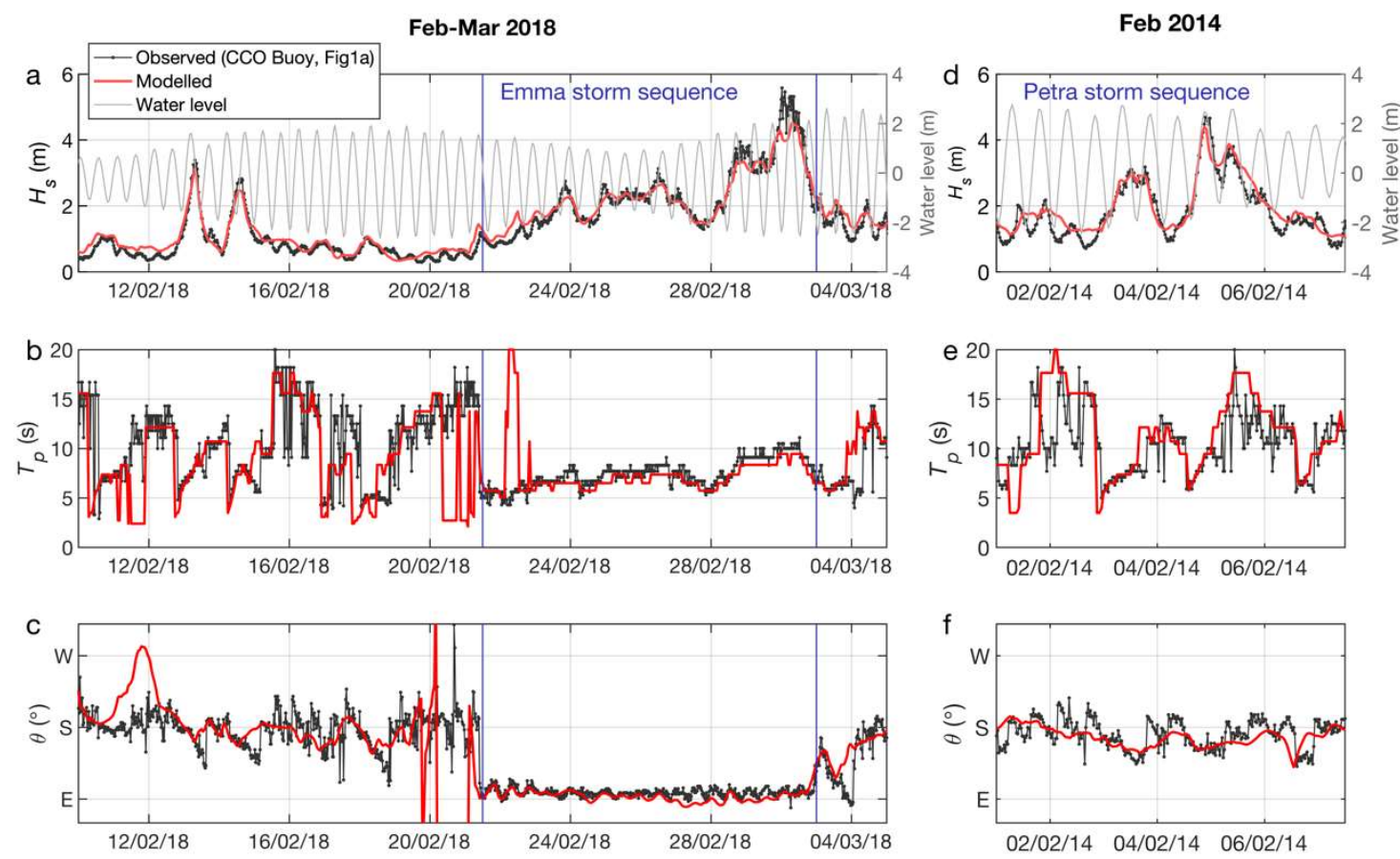

Figure 3. Time series of wave observations at the CCO wave buoy (Fig. 1a) and the WAVE model, including: (ac) significant wave height $\left[H_{s}\right]$, peak period $\left[T_{p}\right]$ and mean direction $[\vartheta]$ for a section of the calibration period, including easterly Emma storm sequence in 2018; and (d-f) wave parameters for southerly Petra storm sequence in 2014. 
Refraction and wind growth were switched on in the WAVE model. Diffraction was not used as it requires grid cells to be $<10 \%$ the wavelength ( $5 \mathrm{~m}$ for short period waves), which is not viable computationally and is only likely to be a factor in the immediate vicinity of structures (Deltares, 2014). The breaking coefficient for the WAVE model $\left(\gamma_{W A V E}\right)$ was set to 0.6 (note this is different to the gravel beach value described above; $\gamma_{\text {shore }}=0.7$ ), based on calibration against the southern ADCP during storm Emma, during which time significant breaking occurred over the Skerries Bank. After initial testing, the model was found to overpredict wave heights near the shoreline for waves from the SW. This may in part be due to overprediction in the boundary conditions, with the Met Office WWIII model found to exceed the UoP Buoy observations by $5-10 \%$ during low-moderate southerly conditions, but may also be related to insufficient wave attenuation in the WAVE model for high angles of refraction. Alterations to model settings to increase wave attenuation of the SW waves were found to also attenuate E wave directions. As an alternative, a highly effective workaround was to reduce all S-SW boundary wave heights by $20 \%$, which resulted in extremely low BIAS values for $H_{s}(<0.05 \mathrm{~m}$ for all simulations, Table 2).

The WAVE model performs very well for high-energy events, which are of greatest importance to our analysis, and adequately for moderate energy levels. The great majority of shoreline sediment transport will occur for wave heights > $1.5 \mathrm{~m}$ (cf. Luijendijk et al., 2017); accordingly, we provide skill statistics for $H_{s}>1.5 \mathrm{~m}$ at the CCO Buoy (Fig. 1a), noting that period and direction are poorly predicted for low wave heights. Significant wave height $(>1.5 \mathrm{~m})$, peak period and direction are all well predicted across the embayment for the calibration, validation and storm sequences (Table 2). For $H_{s}, R^{2} \geq 0.8$, $M A E \leq 0.26 \mathrm{~m}$ and $B I A S \leq 0.04 \mathrm{~m}$ for embayment averaged values. Period is well-modelled with MAE and BIAS mostly < $1 \mathrm{~s}$. For wave direction, there are high frequency variations in observed values, but direction is well-modelled when averaged over a tidal cycle or longer, as indicated by the low BIAS (generally $<5^{\circ}$ ). The WAVE model performs slightly less well for the validation period, which included no major storm events and large fluctuations in peak period, a common phenomenon in semi- 
sheltered environments due to the interaction of local wind wave generation and swell wave attenuation for high angles of refraction (King et al., 2019). Given that alongshore transport in Start Bay is dominated by high-energy events (Wiggins et al., 2019a; McCarroll et al., 2019a), we conclude the WAVE model is suitable for the purpose of modelling longshore transport rates.

Table 2: WAVE model skill, for $\boldsymbol{H}_{s}>1.5 \mathrm{~m}$ at the CCO Buoy.

\begin{tabular}{|c|c|c|c|c|c|}
\hline Time period & Variable & Location & $R^{2}$ & MAE & BIAS \\
\hline Calibration & $H_{s}$ & (ALL SITES) & 0.80 & 0.26 & -0.03 \\
\hline \multirow[t]{20}{*}{ Feb-Mar 2018} & & $\mathrm{~A} 1$ (HS) & 0.79 & 0.25 & 0.10 \\
\hline & & A2 (BS) & 0.63 & 0.38 & -0.16 \\
\hline & & A3 (BK) & 0.81 & 0.22 & 0.01 \\
\hline & & A4 (SK) & 0.84 & 0.24 & -0.01 \\
\hline & & CCO buoy & 0.92 & 0.21 & -0.08 \\
\hline & & UoP buoy* & 0.89 & 0.31 & -0.01 \\
\hline & $T_{p}$ & (ALL SITES) & 0.49 & 0.71 & -0.26 \\
\hline & & $\mathrm{A} 1(\mathrm{HS})$ & 0.24 & 0.78 & -0.16 \\
\hline & & $\mathrm{A} 2$ (BS) & 0.13 & 0.82 & 0.08 \\
\hline & & $\mathrm{A} 3$ (BK) & 0.67 & 0.65 & -0.37 \\
\hline & & A4 (SK) & 0.64 & 0.62 & -0.31 \\
\hline & & CCO buoy & 0.79 & 0.70 & -0.54 \\
\hline & & UoP buoy* & 0.52 & 0.89 & -0.43 \\
\hline & $\theta$ & (ALL SITES) & 0.65 & 11.70 & 2.05 \\
\hline & & $\mathrm{A} 1$ (HS) & 0.60 & 10.05 & 2.62 \\
\hline & & A2 (BS) & 0.23 & 19.67 & 5.10 \\
\hline & & $\mathrm{A} 3$ (BK) & 0.75 & 9.01 & 2.88 \\
\hline & & A4 (SK) & 0.77 & 12.49 & 2.19 \\
\hline & & CCO buoy & 0.89 & 7.28 & -2.56 \\
\hline & & UoP buoy* & 0.94 & 11.50 & -5.08 \\
\hline \multirow{3}{*}{$\begin{array}{l}\text { Validation } \\
\text { Mar-Apr } 2018\end{array}$} & $H_{s}$ & (ALL SITES) & 0.62 & 0.24 & 0.03 \\
\hline & $T_{p}$ & (ALL SITES) & 0.15 & 2.38 & 1.75 \\
\hline & $\theta$ & (ALL SITES) & 0.52 & 19.23 & 0.55 \\
\hline \multirow{3}{*}{$\begin{array}{l}\text { Petra } \\
\text { (S storm sequence) }\end{array}$} & $\mathrm{Hs}$ & CCO buoy & 0.87 & 0.25 & 0.04 \\
\hline & $\mathrm{Tp}$ & CCO buoy & 0.64 & 1.81 & 1.38 \\
\hline & $\theta$ & CCO buoy & 0.43 & 11.85 & -5.76 \\
\hline \multirow{3}{*}{$\begin{array}{l}\text { Emma } \\
\text { (E storm sequence) }\end{array}$} & $\mathrm{Hs}$ & CCO buoy & 0.82 & 0.22 & -0.02 \\
\hline & $\mathrm{Tp}$ & CCO buoy & 0.69 & 0.62 & -0.44 \\
\hline & $\theta$ & CCO buoy & 0.12 & 6.67 & 0.17 \\
\hline
\end{tabular}

* The UoP Buoy did not collect data after $3 / 3 / 2018$, skill statistics are for the period prior to this. 
The FLOW model was forced by current velocity at the SW boundary and by water levels at the SE and NE boundaries. Boundary transparency was set to 3000 s during WAVE-FLOW coupled simulations to prevent instabilities in the flow. The FLOW model (Fig. 4) performed excellently with regard to water level $\left(R^{2}=0.95\right)$. Skill is judged against current vectors $(u, v)$, current speed $(U)$ and direction $(D r n)$, for 1-hour averaged values. Residual currents velocities $\left(u_{\text {low }}, v_{\text {low }}\right)$ and speed $\left(U_{\text {low }}\right)$ were determined by applying a 25-hour low-pass Fourier filter to the hourly averages. Both instantaneous and residual currents are well-predicted (Table 3), with $M A E \leq 0.09$ and $B I A S \leq|0.02|$.
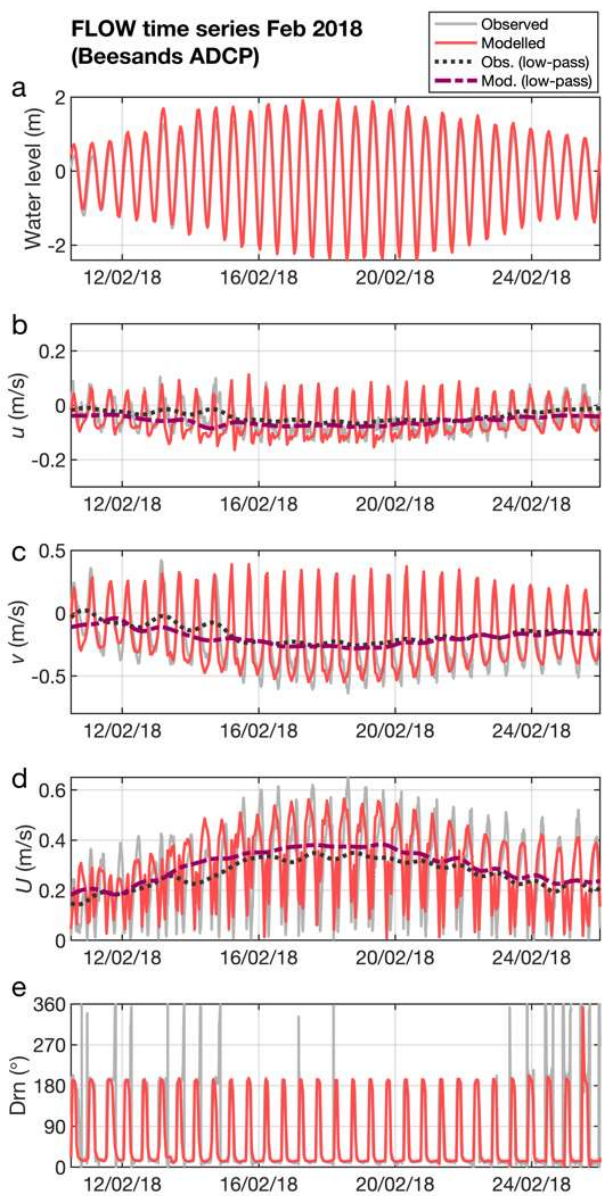

Figure 4. FLOW model validation against observations at the Beesands ADCP (A2, Fig. 1a), for water level, eastwest velocity $(u)$, north-south velocity $(v)$, current speed $(U)$ and direction $(D r n)$. 
Table 3: FLOW model skill, averaged across the four ADCPs (Fig. 1a)

\begin{tabular}{|c|c|c|c|c|c|c|}
\hline \multirow[b]{2}{*}{ Variable } & \multicolumn{3}{|c|}{ Calibration (Feb-Mar 2018) } & \multicolumn{3}{|c|}{ Validation (Mar-Apr 2018) } \\
\hline & $R^{2}$ & MAE & BIAS & $R^{2}$ & MAE & BIAS \\
\hline $\mathrm{WL}(\mathrm{m})$ & 0.95 & 0.23 & 0.02 & 0.95 & 0.24 & -0.11 \\
\hline$u(\mathrm{~m} / \mathrm{s})$ & 0.61 & 0.05 & -0.01 & 0.64 & 0.05 & 0.00 \\
\hline$v(\mathrm{~m} / \mathrm{s})$ & 0.81 & 0.08 & -0.02 & 0.81 & 0.08 & -0.02 \\
\hline$U(\mathrm{~m} / \mathrm{s})$ & 0.58 & 0.09 & 0.02 & 0.59 & 0.09 & 0.02 \\
\hline Drn (deg) & 0.80 & 13.36 & -2.63 & 0.79 & 12.82 & -5.32 \\
\hline$u_{\text {low }}(\mathrm{m} / \mathrm{s})$ & 0.33 & 0.04 & -0.01 & 0.33 & 0.03 & 0.00 \\
\hline$V_{\text {low }}(\mathrm{m} / \mathrm{s})$ & 0.65 & 0.04 & -0.02 & 0.56 & 0.04 & -0.02 \\
\hline$U_{\text {low }}(\mathrm{m} / \mathrm{s})$ & 0.89 & 0.03 & 0.03 & 0.91 & 0.04 & 0.03 \\
\hline
\end{tabular}




\section{Results}

\subsection{Residual tidal flow}

Residual flow around headlands is important for bank formation processes (Berthot and Pattiaratchi, 2006b). We provide a brief examination of residual tidal flow over the Skerries Bank for the control and test bathymetries, though we note our primary concern is with hydrodynamics along the shoreline of the bay. The residual flow in Figure 5 is determined by averaging flow velocities over a complete spring-neap cycle over the period Mar-Apr 2018, using a FLOW-only model (no waves).

The residual flow for the reference case (Fig. 5a) reveals strong $\left(0.5 \mathrm{~m} \mathrm{~s}^{-1}\right)$ and convergent offshore flow on either side of Start Point, with near-zero residual flow near the crest of Skerries Bank, which is consistent with the earlier model of Dyer \& Huntley (1999). Examining the test cases (Fig. 5b-d), the total removal of Skerries Bank (Fig. 5b) results in a stronger residual eddy over the reference bank position, but with minimal differences along the shoreline. The lowering of Skerries (Fig. 5c) causes minimal change to the flow field, while the raising of the bank (Fig. $5 \mathrm{~d}$ ) results in stronger currents at the offshore side of the bank, with minor changes to currents at the shoreline onshore of the bank $( \pm$ $0.05 \mathrm{~m} / \mathrm{s}$ ). In summary, the modifications to Skerries Bank encompassed by our test cases produce only marginal changes to residual currents along the shoreline of Start Bay. Additionally, the observed residual flow pattern is commensurate with hypothesised bank formation mechanisms (e.g., Berthot and Pattiaratchi, 2006b), suggesting the flow component of the model performs well. 

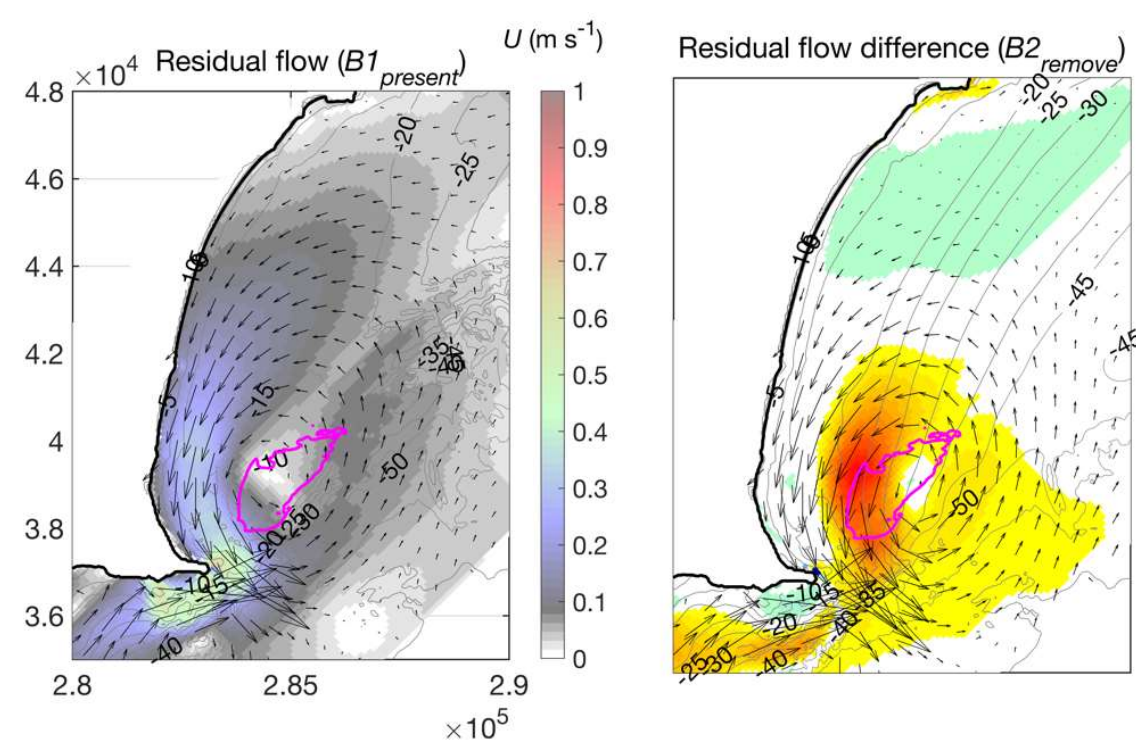

0.3

$0.2 \widetilde{-}$

$-0.1$

0

0
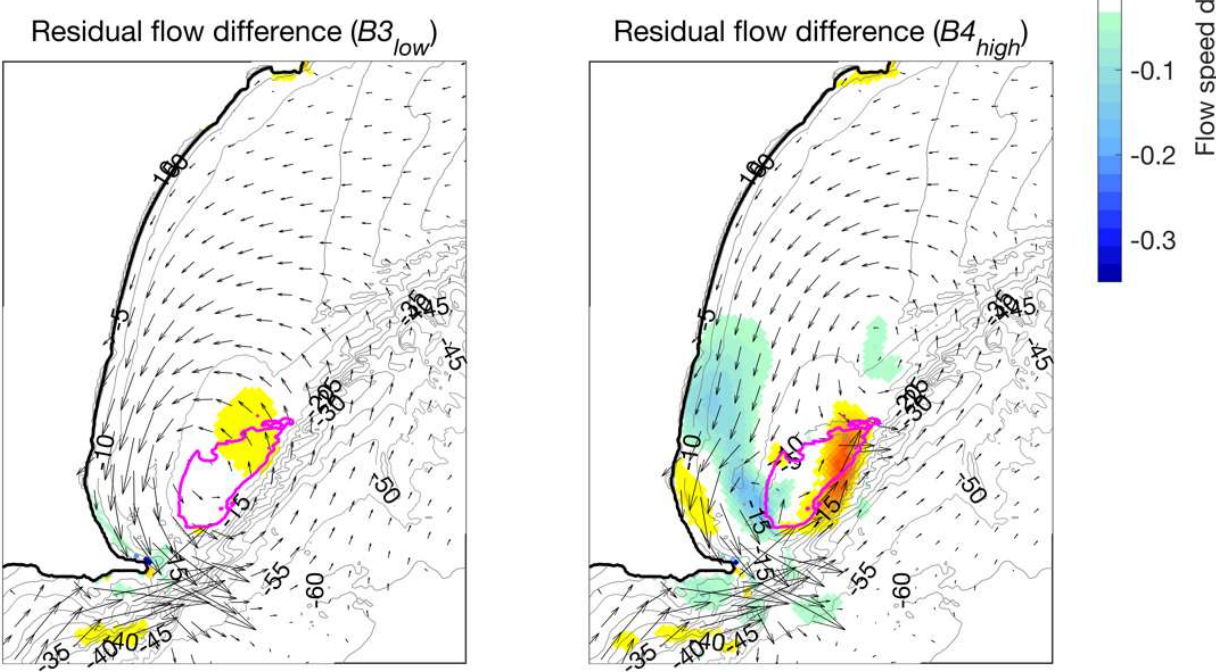

Figure 5. Residual tidal flow for: (a) the control bathymetry [B1 present] and (c-d) the test case bathymetries.

Colour field in (a) is current speed, while colour in (c-d) is the velocity magnitude difference between the test

case and the control. Vectors indicate velocity in all panels. Pink outline in (a) is the 'present' 10-m depth contour of the Skerries Bank, which is replicated in (b-d) for reference.

\subsection{Storm scenarios}

We now test the four bathymetries (Fig. 2) against the two storm scenarios (Fig. 3), including Storm Emma (easterly) and Storm Petra (southwesterly). To spatially investigate the impact of Skerries during extreme energy conditions, wave heights were averaged across the peak of the storm (Fig. 6) 
over approximately half a tidal cycle ( 6 hours), such that the average water level over this period is close to mean sea level.

During Storm Emma (Fig 6-top half), the easterly $5 \mathrm{~m}$ waves can be seen to dissipate through breaking over the Skerries Bank at the peak of the storm (Fig. 6a). If Skerries is removed entirely (Fig 6b) larger waves occur across the southern half of the bay, with $\Delta H_{s}>1 \mathrm{~m}$ near the shoreline in the region of Hallsands (HS in Fig. 6a), and wave directions are rotated northward (positive indicates clockwise rotation in Fig. 6e) along most of the bay, due to lower refraction over the deeper bed (Fig. 2b). Similar effects are seen for the lowering of the bank $\left(B 3_{\text {low; }}\right.$ Fig. $\left.6 c, f\right)$, though with lower magnitudes and restricted in area to onshore of the bank at the southern end of the bay. Raising the bank during the easterly storm ( $B 4_{\text {high }}$ Fig $6 \mathrm{~d}, \mathrm{~g}$ ) produces the opposite effect at the south end of the bay, reducing wave heights through increased breaking, and rotating waves southward due to increased refraction as waves pass over the shallower bank.

For southwesterly Storm Petra (Fig. 6-bottom half), waves outside the bay and offshore of Skerries are $\geq 5 \mathrm{~m}$, but wave heights within the bay average $\leq 4 \mathrm{~m}$, decreasing toward the south, due to the protection offered by Start Point and Skerries. Removal of Skerries for the southerly storm allows for greater westward refraction toward the coast (negative area in Fig. 6I), which creates a focussing point of higher waves around Beesands (BS; Fig. 6i). The lowering (B3 low; Fig. 6j,m) and raising (B4high; Fig. $6 \mathrm{j}, \mathrm{m})$ of the bank during the southerly storm produces analogous effects to the easterly, in that refraction and dissipation are decreased (increased) when the bank is lowered (raised). However, given the change in wave angle, the zone of the bay which is impacted is shifted northward, now affecting wave height over a large area, from BS to STR. 

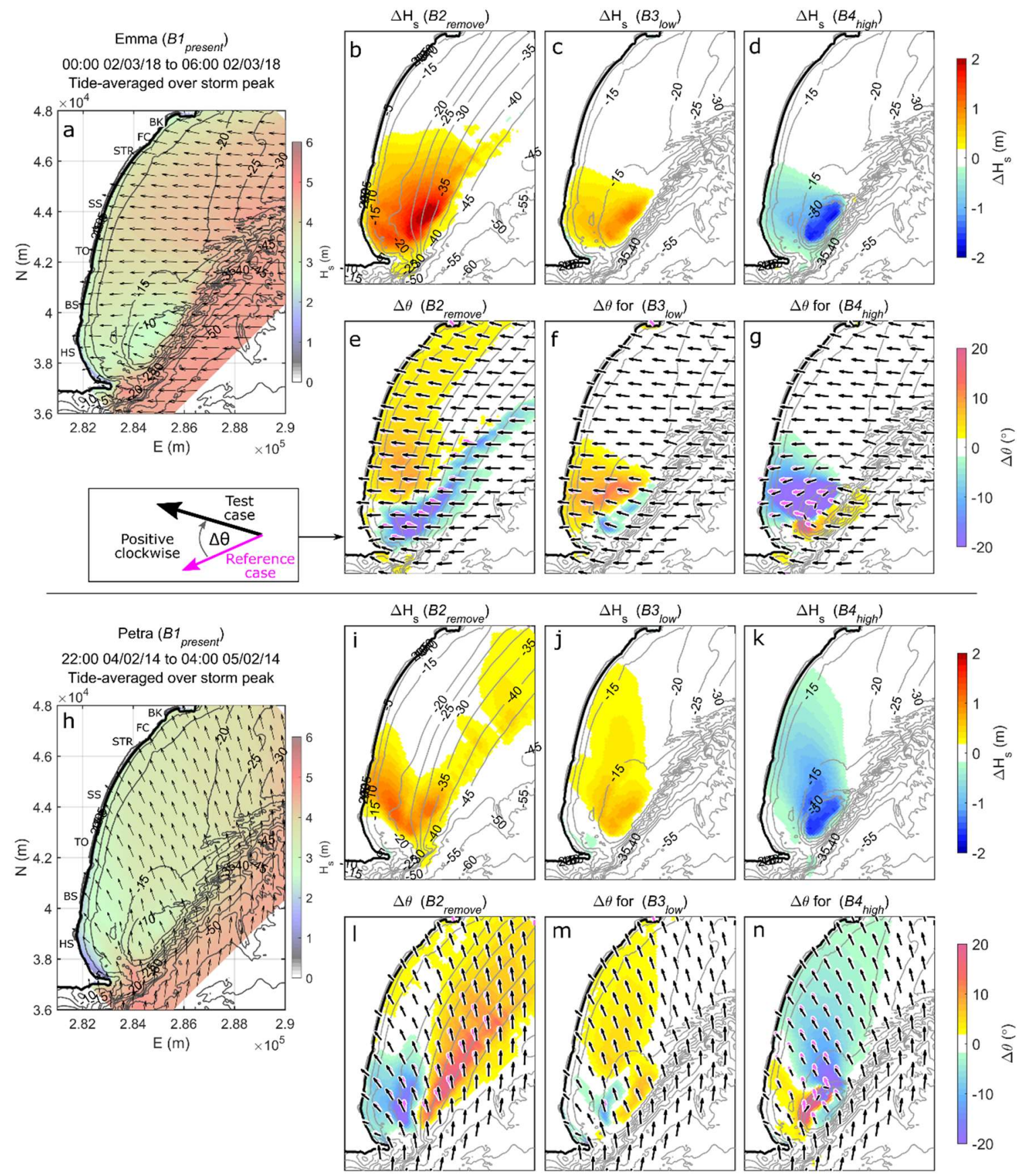

Figure 6. Synoptic overview of storm scenarios, 6-hour averages over the storm peak, for Storm Emma (top half, a-g) and Petra (bottom half, $h-n)$. Wave height and direction for control bathymetry $\left(1^{\text {st }}\right.$ column; a,h; $B 1_{\text {present }}$. For test cases ( $2^{\text {nd }}$ to $4^{\text {th }}$ columns), wave height and direction are shown as relative differences from the control. Locations indicated in (a,h): Hallsands (HS); Beesands (BS); Torcross-Slapton Sands-Strete (TO-SSSTR); Forest Cove (FC); and Blackpool Sands (BK). 
The cumulative impact of the south and east storms on longshore transport are summarised in Fig. 7. Here, the mean breaking wave heights and breaking angle relative to shore are averaged over the full storm sequence ( 9.5 days for Emma, 7 days for Petra). The breaking wave values are found by extracting wave variables from the Delft3D model at the $14-\mathrm{m}$ contour and transforming to the breakpoint using (Eqs. 1-2). Alongshore wave power is calculated for each time-point (Eq. 3) and cumulative alongshore potential sediment flux is determined (Eq. 4, CERC) for each point along the shoreline. For these extreme storm conditions, a transport coefficient of $K=0.26$ is used for the CERC equation, which is the value observed at this location over the storm Emma sequence (McCarroll et al., 2019a). It is important to note these are 'potential' flux rates, as they assume available sediment at all locations, at all times. Due to sediment shortages around headlands in this setting, it is of limited use to look at gradients in longshore transport to determine volume change, as this assumes abundant updrift sediment supply, and we therefore examine total potential sediment flux, for a fixed shoreline position. In reality, headlands along the embayment act like groynes to temporarily block some or all transport (McCarroll et al., 2019a) until sufficient sediment has built up against the headland to allow greater bypassing to occur. Rates of bypassing and the actual longshore flux rates are therefore time, space- and storm-sequence dependent (Vieira da Silva, 2018) and are beyond the scope of this study.

The maximum total alongshore sediment flux rates for the Emma sequence are on the order of $200,000 \mathrm{~m}^{3}$, in the region around STR (Fig. 7f). In this instance, the potential (modelled) rates have been robustly confirmed by observation to match the actual rates (McCarroll et al., 2019a). The impact of varying the Skerries bank bathymetry under the forcing of easterly Storm Emma (Fig. $7 b, d, f)$ is primarily restricted to the southern end of the embayment. Mean significant wave heights south of $\mathrm{HS}$ are increased by $0.2 \mathrm{~m}$ for the 'Skerries removal' case (Fig. $7 \mathrm{~b} ; B 2_{\text {remove }}$ ) and to a lesser degree for the lowering ('mining') case $\left(B 3_{\text {low }}\right)$. Raising the bank has a more marked effect, reducing mean wave heights by up to $0.4 \mathrm{~m}$ and increasing the angle at breaking by up to $5^{\circ}$ (Fig. $7 \mathrm{~d}$; negative values indicate 
southward transport) from TO to HS. The net effect on transport is that removing or lowering the bank would result in increased northward transport for the far-southern sector (south of HS), while raising the bank would drastically reduce northern transport in this region, especially for the area just south of Hallsands. This will be discussed further in Section 7 as it relates to the destruction of the Old Hallsands village in this region. Net southward transport is greater at BS for the raised bank scenario (Fig. 7f; $B 4_{\text {high }}$ ) due to the increased wave angle offsetting the decrease in wave heights. Southward transport along SS is marginally lower for the removal test case (Fig. $7 f ; B 2_{\text {remove }}$ ), due to reduced refraction in the deeper outer northern section of the embayment.

For the Petra sequence, maximum potential transport flux is on the order of $100,000 \mathrm{~m}^{3}$, occurring in the STR region (Fig. 7g), which is 50\% that of Storm Emma (Fig. 7f). The alongshore impact (Fig. 7c,e,g) is most pronounced for the Skerries 'removal' test case in the BS region (locations indicated in Fig. 7a). For $B 2_{\text {remove, }}$ the wave heights are increased by $0.4 \mathrm{~m}$ (Fig. 7c, green line) and the longshore transport rates are doubled (Fig. $7 \mathrm{~g})$. By comparison, for the Skerries lowering or 'mining' test case $\left(B 3_{\text {low }}\right)$, only a slight increase in $H_{s}$ is predicted at the mid-south section of the bay, near BS (Fig. 7c, orange dotted line), with the wave height increase becoming more pronounced further north at STR. This results in increased northward transport rates of up to $20,000 \mathrm{~m}^{3}$ around STR (Fig. $7 \mathrm{~g}, \mathrm{~B} 3_{\text {low }}$ ). The raised bank test case $\left(B 4_{\text {high }}\right)$ produces a substantial impact during Petra, with wave heights lowered by $0.2 \mathrm{~m}$ along a large section of the bay (Fig. 7c, BS to STR), combined with a decrease in wave angle from SS to STR (Fig. 7e, red dashed line), these effects combine to result in a widespread reduction in northward longshore transport, lowering cumulative transport by up to half at BS and TO. 

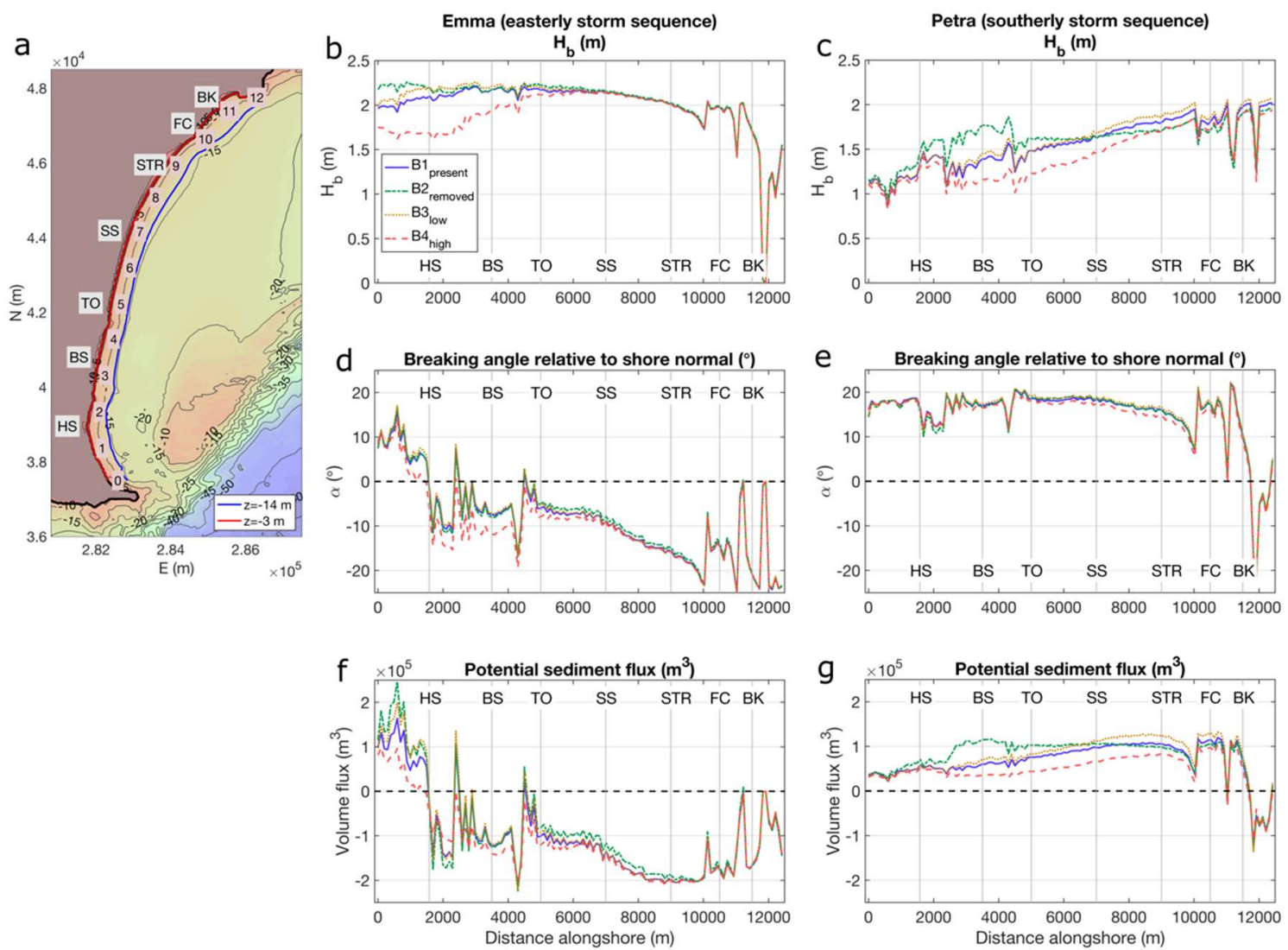

Figure 7. Average significant wave height $(b, c)$, average wave direction (d,e) and cumulative potential sediment

flux (f,g) for Emma (middle column) and Petra (right column). Locations: Hallsands (HS); Beesands (BS); Torcross-Slapton Sands-Strete (TO-SS-STR); Forest Cove (FC); and Blackpool Sands (BK). 


\subsection{Correlating bank depth with shoreline flux rates}

The influence of bank depth and shoreline-bank distance is now examined quantitatively (Fig. 8) and relationships are determined between wave forcing, bank crest depth $\left(h_{\text {bank }}[\mathrm{m}]\right)$ and alongshore flux. Attention is focussed on the Hallsands area (HS in Fig. 7a), directly onshore of the bank under easterly waves, where correlations between bank height and shoreline dynamics were found to be strongest. This analysis takes advantage of the varying tidal levels during the storm sequence (Fig. 3a, model time-step of 1-hr), and hence the varying depth over the bank crest. Given the spring tidal range ( $>4 \mathrm{~m})$ and the bank elevation difference of \pm 5 between the 'present', 'high' and 'low' bathymetries (Fig. 2e), it is possible to analyse a near-continuous distribution of bank depths, between approximately $0 \mathrm{~m}$ and $15 \mathrm{~m}$, across a range of wave conditions (Fig. 8). The impact at the shoreline is analysed relative to bank depth, in terms of: (i) the normalised difference in significant wave height from offshore to the breakpoint $\left[\Delta H_{s, \text { ratio }}\right]$, e.g., $\Delta H_{s, \text { ratio }}=-0.2$ represents a $20 \%$ reduction in wave height [Fig. 8a]; and (ii) the change in wave angle between offshore and the break point [Fig. $8 b]$. Variations in wave height and degree of refraction will directly influence alongshore wave power, which is proportional to flux rates [Fig. 8c]. 

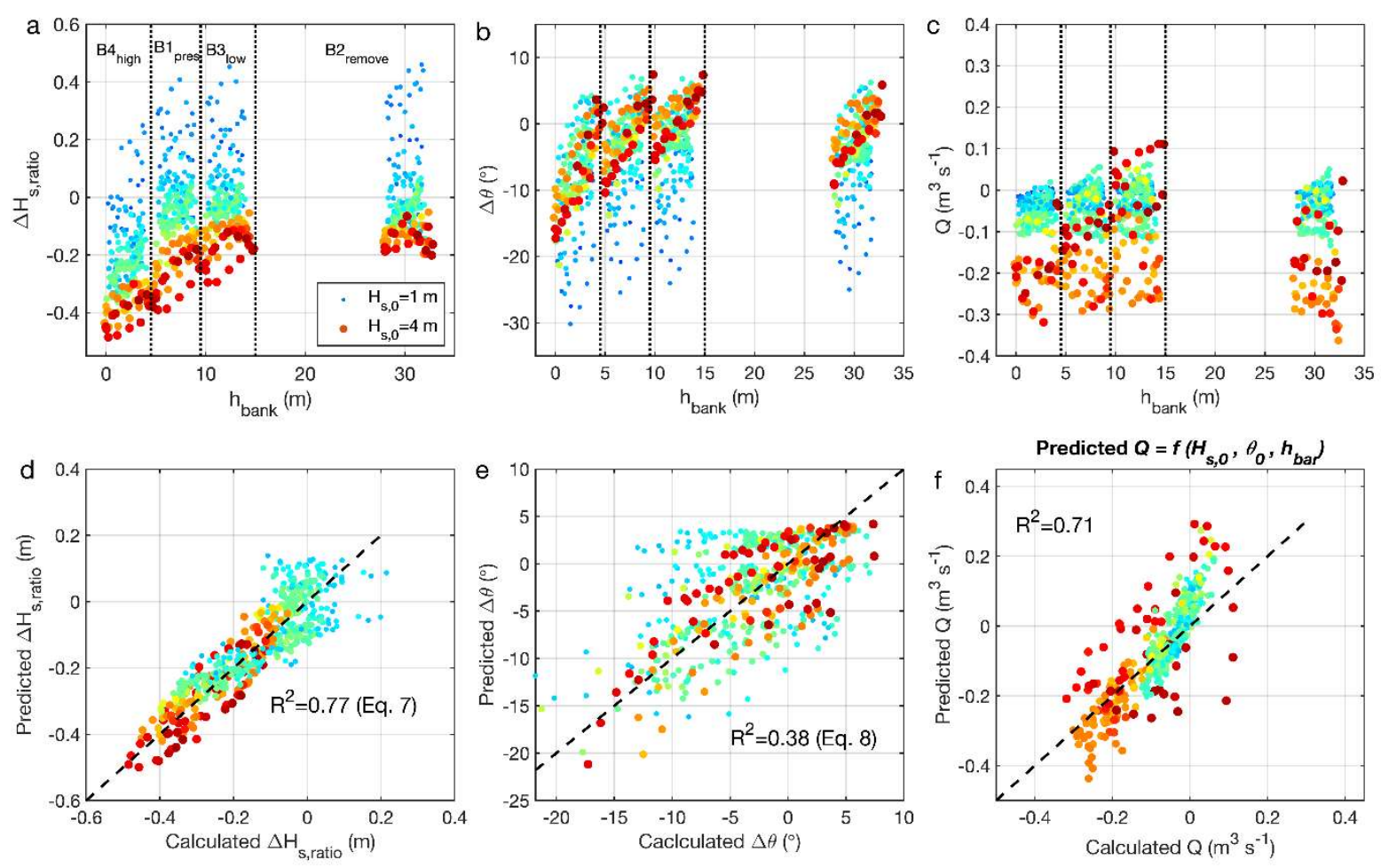

Figure 8. Bank depth control on wave height, direction and alongshore wave power for Hallsands during the easterly storm sequence. Dot colour (all panels) is offshore significant wave height. (a) relative change in wave height from offshore to the breakpoint against depth over the bank crest $\left[h_{\text {bank }}\right]$, vertical dotted lines demarcate scenarios [ $B 1$ to $B 4]$; (b) change in wave direction from offshore to the breakpoint against $h_{\text {bank }}$;

(c) longshore flux and $h_{\text {bank }}$; and (d-f) correlations between forcing variables and shoreline response for scenarios $\left[B 1_{\text {present }}, B 3_{\text {low }}\right.$, and $\left.B 4_{\text {high }}\right]$, described further in the text. Low energy conditions $\left(H_{s, 0}<1.5 \mathrm{~m}\right)$ and scenario $\left[B 2_{\text {remove }}\right]$ were omitted from the correlations in (d-f).

Wave height transformation (Fig. 8a) shows a clear visual correlation across scenarios $\left[B 4_{h i g h}\right.$, $B 1_{\text {present }}$ and $\left.B 3_{\text {low }}\right]$, that appears to be a function of both bank depth $\left(h_{\text {bank }}\right)$ and offshore wave height $\left(H_{s, 0}\right.$; indicated by colour throughout Fig. 8). A strong linear relationship $\left(R^{2}=0.77 ;\right.$ Fig. $\left.8 \mathrm{~d}\right)$ was determined for $\Delta H_{s, r a t i o}$, taking the gradient as a function of $h_{\text {bank }}$ and the y-intercept as a function of $H_{s, 0}$.

$$
\Delta H_{s, \text { ratio }(\text { Hallsands,Emma) }}=0.0267 h_{\text {bank }}-\left(H_{s, 0}+0.7\right) / 10
$$


For transformation of wave angle (Fig. 8b), a weaker correlation $\left(R^{2}=0.38\right.$; Fig. 8e) was determined as a parabolic function of bank depth:

$$
\Delta \theta_{(\text {Hallsands,Storm Emma })}=13 h_{\text {bank }}^{0.3}-25
$$

While at first glance there is no obvious relationship between bank depth and alongshore wave power (Fig. 8c), it is possible to use the relationships established above $($ Eqs. 7,8$)$ to predict breaking wave height and angle (Fig. 8d,e), which may then be used to estimate longshore sediment flux (Eqs. 3,4). Applying this approach, the predicted flux values are skilful (Fig. $8 f, R^{2}=0.71$ ). This suggests it may be possible to predict changes in longshore flux forced by changes to the height of the bank. As this relationship is continuous, it is implied that even small changes to bank height $(<5 \mathrm{~m})$, will have an impact on shoreline flux.

In contrast to the above relationship for Hallsands during the easterly sequence, correlations between bank depth and shoreline dynamics for other regions were weak or absent. This may be due to more non-linear dynamics as the distance from the bank to the shoreline increases, and due to more directional variability during southerly storms. In summary, the analysis in this section (Fig. 8), suggests that simple parameters to predict instantaneous shoreline flux impacts due to changes in bank height may be possible for locations that are directly in the lee of the bank, but may be limited to more qualitative relationships for distal locations. 


\section{Decadal sediment transport rates}

The impact of bi-directional storms are useful for gauging the short-term shoreline impacts of modifying Skerries; however, we also seek some insight into potential long-term (decadal) changes that may occur. While it is not computationally possible to run a process-based model like Delft3D for such extended time periods (referred to as the 'Brute Force' approach herein; previously described in section 3.4), we can use look-up and interpolation ('Interp' method herein; previously described in section 3.6) to transfer the boundary wave condition to inshore points. Both the 'Brute Force' and 'Interp' methods estimate potential longshore transport (section 3.5) for a fixed shoreline position and do not incorporate sediment supply shortages related to headlands and rocky areas.

This 'Interp' approach was first calibrated against the 'Brute Force' approach for the Emma and Petra storms analysed above (section 5), using $K=0.26$ (Eq. 4). The 'Interp' model applies a uniform boundary condition and does not include wave growth due to wind within the domain. These necessary simplifications were found to result in systematic inaccuracies in wave height $\left(H_{s}\right)$ and direction $(\theta)$ when compared to the 'Brute Force' model, which can be corrected with coefficients. For wave height, the correction factor $(\lambda)$ is:

$$
H_{s, \text { corrected }}=\lambda H_{\text {s,interp }, \text { raw }}
$$

and for wave direction, a systematic rotation around a focal point is made:

$$
\theta_{\text {corrected }}=\beta\left[\left(S_{i}-S_{\text {focus }}\right) / S_{\text {focus }}\right] \theta_{\text {interp,raw }}
$$

where $S_{i}$ is the distance alongshore for a given point along the $-14 \mathrm{~m}$ contour, $S_{\text {focus }}$ is the focal point around which the rotation is made and $\beta$ is the maximum rotation angle. For easterly waves (boundary $\theta$ from $70^{\circ}$ to $\left.110^{\circ}\right), \lambda=1.35, \beta=7^{\circ}$ and $S_{\text {focus }}=8500 \mathrm{~m}$ alongshore. For southwesterly waves (boundary $\theta$ from $150^{\circ}$ to $260^{\circ}$ ), $\lambda=1.5$ and no rotation of wave direction was necessary. Using this approach resulted a very good match between the 'Interp' and 'Brute Force' methods, for both the easterly (Fig. 9a) and southwesterly (Fig. 9b) storm sequences, in terms of the resultant alongshore 
transport rates at the shoreline. We note some minor areas of disagreement between the modelling approaches, e.g., 'Interp' overestimates northward transport for Petra at $8000 \mathrm{~m}$ alongshore for the $B 3_{\text {low }}$ case (Fig. 9b), and underestimates for $B 4_{\text {high }}$ in the same region. Overall, the 'Interp' method is judged to be suitable for providing indicative predictions of long-term transport.

The 'Interp' method was then applied to produce a 38.5 year hindcast (Jan 1980 to Jun 2018), using boundary conditions from the Met Office WW3 model (see section 3.6). The long-term prediction of potential longshore transport rates for the reference case $\left(B 1_{\text {present }}\right)$ is given in Figure $9 c$. Predicted 1980-2018 flux rates are generally northward, due to the dominance of SW waves over this period ( $75 \%$ of all waves; Fig. $1 b, c)$. Headlands in Figure $9 c$ can be identified as regions were the 'potential' northward flux rapidly reverses, e.g., BS-TO and STR-FC, though for the reasons stated in section 5.2, it is unlikely this represents the real rates of flux at the headlands. Rates of predicted flux along long, open beaches where sediment is always available (e.g., TO-SS-STR) are more likely to represent realistic transport rates. Here, three values are used for the CERC equation transport rate coefficient (uncertainty bounds in Fig. 9c), ranging from $K=0.04$, a typical value for gravel (Van Rijn, 2014), to $K$ $=0.26$. A mid-point value of $K=0.15$ results in a total northward flux on the order of $5 \mathrm{M} \mathrm{m}^{3}$ along Slapton Sands (SS), which equates to $130,000 \mathrm{~m}^{3} \mathrm{yr}^{-1}$. For the low-end bound $(K=0.04)$, the annual transport rate is $\sim 35,000 \mathrm{~m}^{3} \mathrm{yr}^{-1}$. These values are commensurate with Chadwick et al. (2005), who, using a comparable numerical approach, determined a northerly transport rate of $\sim 150,000 \mathrm{~m}^{3} \mathrm{yr}^{-1}$ during energetic years, and a mean annual rate of 50,000 to $75,000 \mathrm{~m}^{3} \mathrm{yr}^{-1}$.

For the test cases (Fig. 9d) a rate of $(K=0.15)$ was used for all scenarios. For the bank 'removal' case

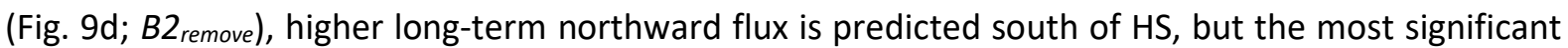
increases are predicted around Beesands (BS) and Torcross (TO). Both BS and TO have limited sediment supply to the south under the present regime, and the predicted increase in flux if Skerries were removed would likely result in massive erosion at these locations. For the bank 'mining/lowering' 
scenario (Fig. 9d; $B 3_{\text {low }}$ ), long-term impacts are predicted to be limited across the southern section of the embayment; however, increased northerly transport rates are expected for STR-FC, potentially moving more sediment north to Blackpool Sands (BK). The final test case of raising the bank (Fig. 9d; $B 4_{\text {high }}$ ) results in lower long-term transport at the far south end of Start Bay, and most significantly, very large reductions in transport along the Slapton Sand embayment (TO-SS-STR), with cumulative northward flux decreasing to near-zero at the mid-point of SS and reversing to net southward transport north of Strete (STR). Over time, this would result in significant accretion over the middle section of Slapton Sands. This is of interest as this region is currently eroding rapidly, with the road on the crest of the barrier having been destroyed twice by storms since 2000 . 

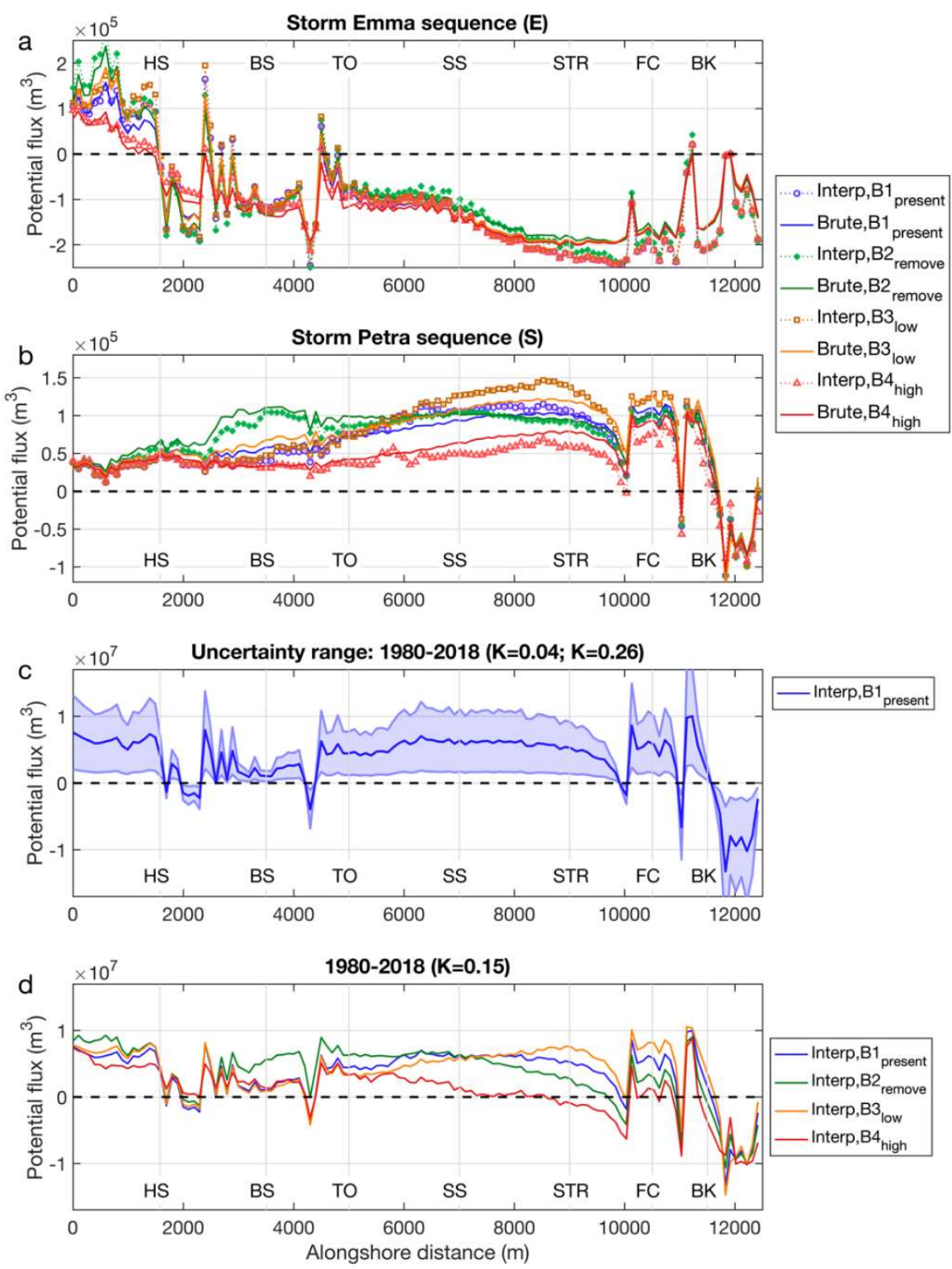

Figure 9. Interpolation/Look-up model, including: (a) calibration of control and test scenarios for easterly Storm Emma, solid lines are 'Brute Force' model, symbols are 'Interp' model; (b) similar calibration for southwesterly storm Petra; (c) long-term prediction of cumulative potential longshore flux for control case, showing uncertainty range using CERC equation $\mathrm{K}$ values of $[\mathrm{low}=0.04$; $\mathrm{mid}=0.15$; $\mathrm{high}=0.26]$; and $(\mathrm{d})$ longterm prediction for all test cases. Locations: Hallsands (HS); Beesands (BS); Torcross-Slapton Sands-Strete (TOSS-STR); Forest Cove (FC); and Blackpool Sands (BK). 


\section{Discussion}

The impacts of individual storms (section 5) and long-term longshore transport predictions (section 6) for each of the test case bathymetries are summarised in Figure 10. We then discuss the implications of this case study in the context of other similar headland-associated sandbanks, including the potential impacts of mining or nourishing sandbanks, and the potential for long-term impacts on shorelines.

The response of the system was broadly as expected, in that lowering (or removing) the bank typically resulted in increased wave exposure in the lee of the bank, with the affected area shifting based on the wave direction, such that for easterly storms the exposed area is toward the south (Fig. 10a,b), with a shift northward under southerly waves (Fig. 10e,f). By contrast, when the bank was raised, a wave shadow zone occurs in the lee of the bank (Fig. 10c,g). Changes to wave height were generally the dominant factor in determining changes to longshore flux rates such that regions of increased (decreased) wave height correlate with regions of increased (decreased) sediment flux. There are some exceptions where changes to wave height and refraction acted in opposite directions (Fig. 10b,c). These outcomes are synthesized in Figure 10 (fourth column). For direct storms (Fig. 10d), increased bank height results in decreased wave heights, breaking angle and longshore sediment flux at the shoreline at the far southern end of the embayment. For oblique storms (Fig. 10h), as bank height increases, storm-averaged wave height and flux decrease along the central section of the bay.

Decadal rates of longshore transport (Fig. 10-third row) are the result of combining the signatures of southerly and easterly wave events. Given that southerly events have been dominant over the 19802018 hindcast period, increases to long-term northerly transport are likely to further increase existing erosion problems at the southern end of the embayment (HS, BS, TO). When the cumulative decadal response is examined (Fig. 10l), only the southern corner displays a consistent negative relationship 
between bar elevation and flux. This is the only area of the bay where both wave directions (easterly and southerly) will produce the same direction of transport (northward). For the remainder of the bay, the cumulative response is highly non-linear (Fig. 10l) due to the bi-directional drift regime. This implies that bi-modal wave climates will complicate simplified predictions of long-term shoreline impacts due to sandbanks. The clearest long-term impacts are that: (i) full bank removal would result in increased northward transport and exacerbate erosion across the southern half of the embayment (Fig. 10i); while, (ii) raising the bank would substantially reduce potential northward transport across the far south and the northern half of the embayment (Fig. 10k), likely reducing the long-term erosion impacts at HS and mid-SS. While the case study approach taken here is useful for validating modelling against real-world observations and allows for some degree of conceptual generalisation (Fig. 10), an idealised model (cf. Berthot and Pattiaratchi, 2006a,b) is required to further generalise or parameterise relationships between offshore bank characteristics and shoreline impacts. 


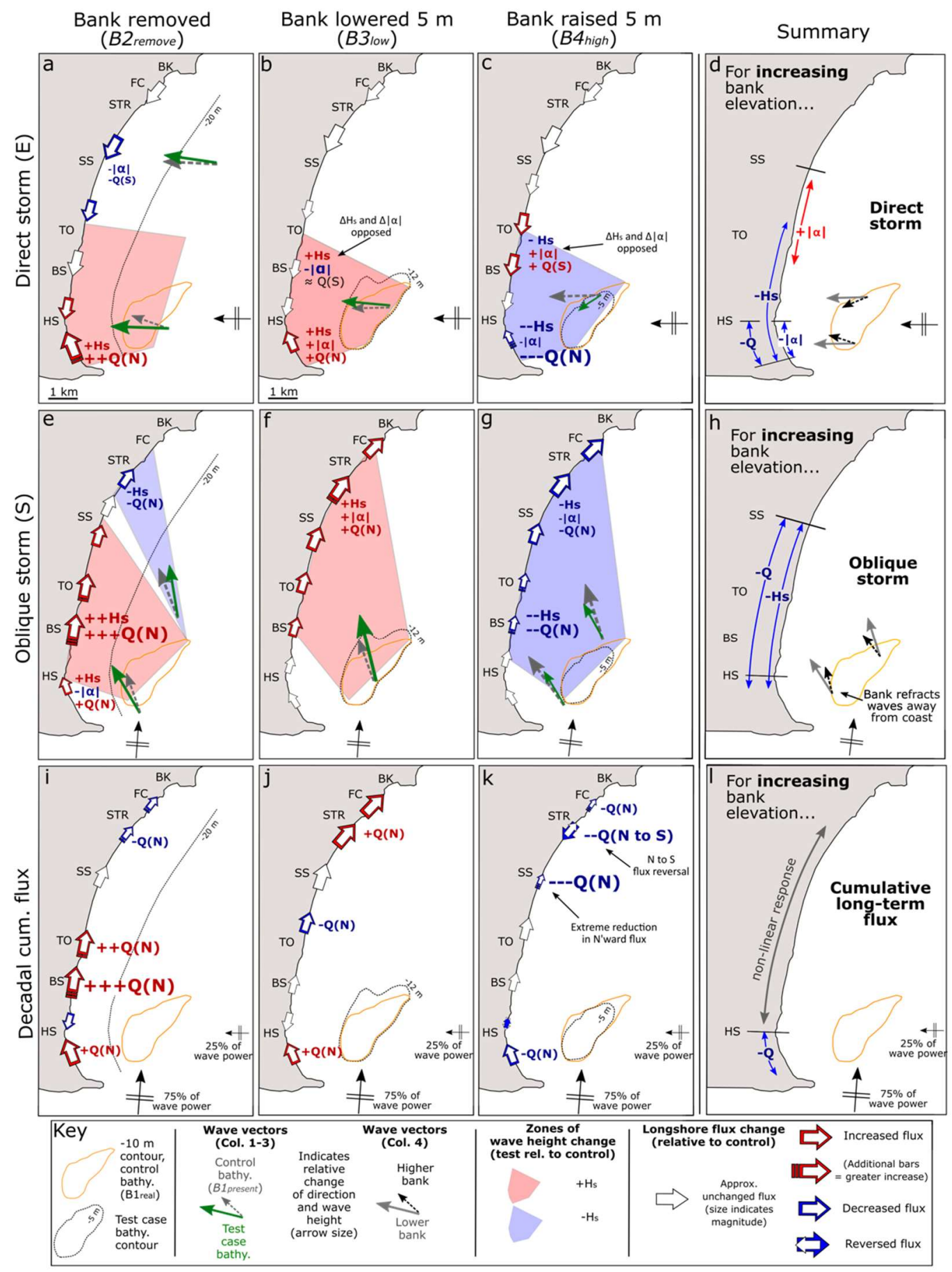

Figure 10. Summary cartoon of test case results relative to the control case, for (a-d) direct storm scenarios; (eh) oblique storm scenarios; and (i-I) decadal scale cumulative flux. Column 1 is for the bank removal case, column 2 is the bank lowering case, column 3 is the raised bank case, and column 4 summarises the results. 
The results presented here have implications for the mining of sandbanks. Moderate reductions in elevation ( $\leq 5 \mathrm{~m}$ ) were shown to have significant impacts on wave height, direction and longshore transport in the lee of the bank, at distances $>5 \mathrm{~km}$. By contrast, Phillips (2008) suggested that, for headland-associated sandbars in the Bristol Channel, UK, there was low potential for sand mining to impact on shoreline dynamics. More recent observations of the Bristol Channel sandbanks (Lewis et al., 2014) detected changes to sandbank heights and volumes, due to natural processes and/or dredging, that, in light of the outcomes of our study, may be sufficient to alter shoreline dynamics. While there has been much focus on sandbanks around the UK and the North Sea coast of Europe (e.g., Dyer and Huntley, 1999; Van Lancker et al., 2010), there are many other regions globally that have similar banks, where the potential shoreline impacts of mining are also of concern, for example: (i) the ridge and swale topography in the Gulf of Mexico, US (Hayes and Nairn, 2004); and (ii) nearshore banks dredged for beach nourishment in southwest Spain (Roman-Sierra et al., 2011).

This study implies that nourishing of sandbanks could be considered as a protective strategy for some coastlines. One interesting outcome of the Skerries Bank simulations was the large reduction in transport along the middle section of the embayment when the bank was raised $5 \mathrm{~m}$ (Fig. 9c, B4high from SS northward), reducing the annual mean transport from $\sim 10^{5} \mathrm{~m}^{3} / \mathrm{yr}$ to near zero. This opens the potential for nourishing banks to protect coastlines, especially if capped by coarser material (to limit future transport of the nourishment material). Further work would also be required to determine if a nourished bank would be stable (e.g., vulnerability to erosion by storm waves), and to establish the threshold levels of bank height increase required to provide sufficient protection. Our results suggest a few meters of bank-raising may make a big difference. For Start Bay, raising the bank would likely offer some protection to the road on the crest of the SS barrier that is frequently washed away (e.g., Chadwick et al., 2005; McCarroll et al., 2019a). 
Finally, the results of this study have important implications regarding the long-term variability of sandbanks. Dolphin et al. (2007) and Hequette et al. (2009) showed that banks can change extensively through natural processes over centennial timescales, while significant changes may also occur over shorter (decadal) timescales (Lewis et al., 2014). We hypothesise that if Skerries Bank was higher in the past, as is suggested by anecdotal evidence (see section 2), it would have generated greater protection for the region around Hallsands (Fig. 9 bottom row). The village of old Hallsands was destroyed in 1917, which has been attributed in part to dredging of shingle from the beachface gravel at the turn of the $20^{\text {th }}$ century (Hails, 1975a), while ongoing erosion around Hallsands has been attributed to a more southerly-dominated wave climate in recent decades (Wiggins et al., 2017). If Skerries Bank were higher in the past, then lowering of the bank would have contributed to chronic erosion by allowing for increased northerly alongshore transport at the southern end of Start Bay and may be an additional contributing factor in the destruction of Old Hallsands. Additionally, a historical lowering of the bank would contribute to the chronic erosion being experienced at the mid-point of Slapton Sands (SS; Fig. 10k), where roads and infrastructure on the barrier crest have been destroyed and set-back multiple times in recent decades. These impacts are consistent with long-term sandbank variability controls on shorelines inferred to exist on comparable coastlines (Robinson, 1980). Understanding long-term sandbank-shoreline controls may help in predicting and planning for erosion and flooding within an embayment. For example, if the long-term trend (or cyclicity) of sandbank change is known, it will allow for modelling of future longshore transport rates (using the methods described here), which can then be used to aid future shoreline management plans, shoreline protection/nourishment and housing/infrastructure planning. Research in this area is scant, and much of it is focussed in the UK and the North Sea. Thus, while many similar sandbank configurations occur globally, for example in the US (McNinch and Luettich, 2000; Hayes and Nairn, 2004) and Australia (Harris et al., 1992; Berthot and Pattiaratchi, 2006a; Hughes et al, 2008), the natural rates of bank variability, and therefore the potential shoreline impacts, are largely unknown. 


\section{Conclusions}

The impact of a headland-associated sandbank on shoreline dynamics was investigated, for the first time, through a robust numerical modelling experiment, using Start Bay and Skerries Bank, UK, as a case study. Longshore sediment transport rates along the embayment were predicted for two storm directions (direct and oblique), compared to the present (control) bathymetry, against three test cases (bank removed, bank lowered $5 \mathrm{~m}$, bank raised $5 \mathrm{~m}$ ). A look-up/interpolation model was then used to hindcast long-term (1980-2018) potential transport rates.

- Moderate changes in bank elevation ( $\leq 5 \mathrm{~m}$ ) were sufficient to cause significant changes to dissipation and refraction, leading to large magnitude changes in sediment transport rates at the shoreline.

- The bank acts to refract oblique waves away from the adjacent shoreline, providing protection.

- Removing or lowering the bank generally acted to reduce dissipation and increase wave heights, increasing longshore flux in the lee of the bank relative to the wave direction.

- Raising the bank generally had the opposite effect, increasing dissipation and lowering flux. The magnitude of the effect of raising the bank was surprisingly large, reducing transport rates to near-zero across extensive sections of the bay, and even reversing the long-term net flux at the opposite end of the embayment from the bank location.

- For the region directly in the lee of the bank, shoreline sediment flux was shown to be a continuous function of bank elevation. This relationship became more complex or absent for shorelines distal from the bank.

- Varying sandbank elevation, either due to natural variability or aggregate mining, can realistically impact on shoreline morphology, necessitating increased monitoring of sandbank morphology and detailed modelling of existing and future mining prospects. 
- Increasing bank height may have a disproportionate impact on decreasing flux rates at the shoreline, therefore sandbank nourishment could be investigated as future coastal protection strategy.

\section{Acknowledgements}

This work was funded by UK Natural Environment Research Council grant (NE/M004996/1; BLUE-coast project). Our thanks to Peter Ganderton and Aaron Barrett for technical assistance with data collection. Additional data provided by the Channel Coastal Observatory and Plymouth Coastal Observatory, Met Office and UKHO. Observational data used in this study are available from the University of Plymouth PEARL data repository (https://doi.org/10.24382/c3ee-6p96).

\section{References}

Acton, J.R., \& Dyer, C.M. (1975). Mapping of Tidal Currents near the Skerries Bank, Journal of the Geological Society (London), 131(1): 63-68.

Bastos, A. C., Paphitis, D., \& Collins, M. B. (2004). Short-term dynamics and maintenance processes of headland-associated sandbanks: Shambles Bank, English Channel, UK. Estuarine, Coastal and Shelf Science, 59(1), 33-47.

Bergillos, R. J., Rodríguez-delgado, C., \& Ortega-sánchez, M. (2017). Advances in management tools for modeling artificial nourishments in mixed beaches. Journal of Marine Systems, 172, 1-13. https://doi.org/10.1016/j.jmarsys.2017.02.009

Berthot, A., \& Pattiaratchi, C. (2006a). Field measurements of the three-dimensional current structure in the vicinity of a headland-associated linear sandbank. Continental Shelf Research, 26(3), 295317.

Berthot, A., \& Pattiaratchi, C. (2006b). Mechanisms for the formation of headland-associated linear sandbanks. Continental Shelf Research, 26(8), 987-1004.

Brière, C., Roos, P. C., Garel, E., \& Hulscher, S. J. (2010). Modelling the morphodynamics of the Kwinte Bank, subject to sand extraction. Journal of coastal research, 117-126.

Chadwick, A. J., Karunaratne, H., Gehrels, W. R., Massey, A. C., O’Brien, D. \& Dales, D. (2005). A New Analysis of the Slapton Barrier Beach System, UK, Proc. Institution of Civil Engineers, Maritime Engineering, 158, 147-161.

Coughlan, C., Vincent, C. E., Dolphin, T. J., \& Rees, J. M. (2007). Effects of tidal stage on the wave climate inshore of a sandbank. Journal of Coastal Research, 751-756.

Degrendele, K., Roche, M., Schotte, P., Van Lancker, V. R., Bellec, V. K., \& Bonne, W. M. (2010). Morphological evolution of the Kwinte Bank central depression before and after the cessation of aggregate extraction. Journal of Coastal Research, 77-86. 
Deltares, (2014). Delft3D-WAVE, Simulation of short-crested waves with SWAN, User Manual. Deltares, Delft, The Netherlands.

Dolphin, T. J., Vincent, C. E., Coughlan, C., \& Rees, J. M. (2007). Variability in sandbank behaviour at decadal and annual time-scales and implications for adjacent beaches. Journal of Coastal Research, 731-737.

Drucker, B. S., Waskes, W., \& Byrnes, M. R. (2004). The US minerals management service outer continental shelf sand and gravel program: environmental studies to assess the potential effects of offshore dredging operations in federal waters. Journal of Coastal Research, 1-5.

Dyer, K. R., \& Huntley, D. A. (1999). The origin, classification and modelling of sand banks and ridges. Continental Shelf Research, 19(10), 1285-1330.

Fairley, I., Masters, I., \& Karunarathna, H. (2016). Numerical modelling of storm and surge events on offshore sandbanks. Marine Geology, 371, 106-119.

Guillou, N., \& Chapalain, G. (2011). Effects of waves on the initiation of headland-associated sandbanks. Continental Shelf Research, 31(11), 1202-1213.

Hails, J. R. (1975a). Some Aspects of the Quaternary History of Start Bay, Devon, Field Studies, 4(2): 207-222.

Hails, J. R., (1975b). Submarine geology, sediment distribution and Quaternary history of Start Bay, Devon: Introduction. Journal of the Geological Society, 131: 1-5.

Hails, J.R., \& Carr, A.P. [eds] (1975). Nearshore Sediment Dynamics and Sedimentation: an Interdisciplinary Review, John Wiley and Sons Ltd, London, 316 pp.

Harris, P. T., Pattiaratchi, C. B., Cole, A. R., \& Keene, J. B. (1992). Evolution of subtidal sandbanks in Moreton Bay, eastern Australia. Marine Geology, 103(1-3), 225-247.

Hayes, M. O., \& Nairn, R. B. (2004). Natural maintenance of sand ridges and linear shoals on the US Gulf and Atlantic continental shelves and the potential impacts of dredging. Journal of Coastal Research, 138-148.

Héquette, A., Ruz, M. H., Maspataud, A., \& Sipka, V. (2009). Effects of nearshore sand bank and associated channel on beach hydrodynamics: implications for beach and shoreline evolution. Journal of Coastal Research, 59-63.

Hequette, A., \& Aernouts, D. (2010). The influence of nearshore sand bank dynamics on shoreline evolution in a macrotidal coastal environment, Calais, Northern France. Continental Shelf Research, 30(12), 1349-1361.

Hitchcock, D. R., \& Bell, S. (2004). Physical impacts of marine aggregate dredging on seabed resources in coastal deposits. Journal of Coastal Research, 101-114.

Holmes, P. K. (1975a). Wave Conditions in Start Bay, Journal of the Geological Society (London), 131(1), 57-62.

Holmes, P. (1975b). Wave Conditions in Coastal Areas, in: J. R. Hails and A. P. Carr (Eds) Nearshore Sediment Dynamics and Sedimentation, Chichester: John Wiley, 1-15.

Hughes, M. G., Harris, P. T., Heap, A., \& Hemer, M. A. (2008). Form drag is a major component of bed shear stress associated with tidal flow in the vicinity of an isolated sand bank, Torres Strait, northern Australia. Continental Shelf Research, 28(16), 2203-2213.

Kelland, N. C. (1975). Submarine Geology of Start Bay Determined by Continuous Seismic Profiling and Core Sampling, Journal of the Geological Society (London), 131(1), 7-17. 
King, E.V., Conley, D.C., Masselink, G., Leonardi, N., McCarroll, R.J., \& Scott, T. (2019). The Impact of Waves and Tides on Residual Sand Transport on a Sediment-poor, Energetic and Macrotidal Continental Shelf. Journal of Geophysical Research: Oceans.

Lesser, G. R., Roelvink, J. V., Van Kester, J. A. T. M., \& Stelling, G. S. (2004). Development and validation of a three-dimensional morphological model. Coastal engineering, 51(8-9), 883-915.

Lewis, M. J., Neill, S. P., \& Elliott, A. J. (2014). Interannual variability of two offshore sand banks in a region of extreme tidal range. Journal of Coastal Research, 31(2), 265-275.

Luijendijk, A. P., Ranasinghe, R., de Schipper, M. A., Huisman, B. A., Swinkels, C. M., Walstra, D. J., \& Stive, M. J. (2017). The initial morphological response of the Sand Engine: A process-based modelling study. Coastal engineering, 119, 1-14.

Masselink, G., Scott, T., Poate, T., Russell, P., Davidson, M., \& Conley, D. (2016). The extreme 2013/2014 winter storms: hydrodynamic forcing and coastal response along the southwest coast of England. Earth Surface Processes and Landforms, 41, 378-391.

May, V. J., \& Hansom, J. D. (2003). Coastal Geomorphology of Great Britain, Geological Conservation Review Series 28, Joint Nature Conservation Committee.

McCarroll, R.J., Masselink, G., Wiggins, M., Scott, T., Billson, O., Conley, D.C., \& Valiente, N.G., (2019a). High-efficiency gravel longshore transport and headland bypassing over an extreme wave event. Earth Surface Processes and Landforms.

McCarroll, R.J., Masselink, G., Wiggins, M., Scott, T., Billson, O., \& Conley, D., (2019b). Gravel beach cross- and alongshore response to an extreme event: Beach length and headland proximity controls, in Coastal Sediments, 2019. Florida, USA, World Scientific.

McNinch, J. E., \& Luettich Jr, R. A. (2000). Physical processes around a cuspate foreland:: implications to the evolution and long-term maintenance of a cape-associated shoal. Continental Shelf Research, 20(17), 2367-2389.

O'dea, E.J., Arnold, A.K., Edwards, K.P., Furner, R., Hyder, P., Martin, M.J., Siddorn, J.R., Storkey, D., While, J., Holt, J.T. \& Liu, H. (2012). An operational ocean forecast system incorporating NEMO and SST data assimilation for the tidally driven European North-West shelf. Journal of Operational Oceanography, 5(1), 3-17.

Phillips, M. R. (2008). Beach erosion and marine aggregate dredging: a question of evidence?. Geographical journal, 174(4), 332-343.

Pingree, R. D. (1978). The formation of the Shambles and other banks by tidal stirring of the seas. Journal of the Marine Biological Association of the United Kingdom, 58(1), 211-226.

Robinson, A. H. W. (1961). The hydrography of Start Bay and its relationship to beach changes at Hallsands, Geographical Journal, 121: 63-77.

Robinson, A. H. W. (1980). Erosion and accretion along part of the Suffolk coast of East Anglia, England. Marine Geology, 37(1-2), 133-146.

Roman-Sierra, J., Navarro, M., Muñoz-Perez, J. J., \& Gomez-Pina, G. (2011). Turbidity and other effects resulting from Trafalgar sandbank dredging and Palmar beach nourishment. Journal of Waterway, Port, Coastal, and Ocean Engineering, 137(6), 332-343.

Roos, P. C., Hulscher, S. J., Knaapen, M. A., \& Van Damme, R. M. (2004). The cross-sectional shape of tidal sandbanks: Modeling and observations. Journal of Geophysical Research: Earth Surface, 109(F2).

Ruiz de Alegria-Arzaburu, A., \& Masselink, G. (2010). Storm response and beach rotation on a gravel beach, Slapton Sands, U.K. Marine Geology, 278, 77-99. 
Schmitt, T., \& Mitchell, N. C. (2014). Dune-associated sand fluxes at the nearshore termination of a banner sand bank (Helwick Sands, Bristol Channel). Continental Shelf Research, 76, 64-74.

Scott, T., Masselink, G., Hare, T.O., Saulter, A., Poate, T., Russell, P., Davidson, M., \& Conley, D. (2016). The extreme 2013 / 2014 winter storms : Beach recovery along the southwest coast of England. Marine Geology, 382, 224-241.

Tolman, H. L. (1991). A third-generation model for wind waves on slowly varying, unsteady, and inhomogeneous depths and currents. Journal of Physical Oceanography, 21(6), 782-797.

USACE. (2002). Shore Protection Manual. Coastal Engineering Research Center, Government Printing Office,Washington DC.

Van Lancker, V. R., Bonne, W. M., Velegrakis, A. F., \& Collins, M. B. (2010). Aggregate extraction from tidal sandbanks: Is dredging with nature an option? Introduction. Journal of Coastal Research, 5361.

Van Rijn, L. C. (2014). A simple general expression for longshore transport of sand, gravel and shingle. Coastal Engineering, 90, 23-39.

Vieira da Silva, G., Toldo, E. E., Klein, A. H. d. F., Short, A. D., \& Woodroffe, C. D. (2016). Headland sand bypassing - Quantification of net sediment transport in embayed beaches, Santa Catarina Island North Shore, Southern Brazil. Marine Geology, 379, 13-27.

Vieira da Silva, G. V., Toldo Jr, E. E., Klein, A. H. D. F., \& Short, A. D. (2018). The influence of wave-, wind-and tide-forced currents on headland sand bypassing-Study case: Santa Catarina Island north shore, Brazil. Geomorphology, 312, 1-11.

Wiggins, M.A., Scott, T., Masselink, G., Russell, P., Castelle, B., \& Dodet, G. (2017). The role of multidecadal climate variability in controlling coastal dynamics: re-interpretation of the "Lost Village of Hallsands." In Proceedings of the Proceedings Coastal Dynamics 2017; pp. 96-107.

Wiggins, M., Scott, T., Masselink, G., Russell, P., \& McCarroll, R.J. (2019). Coastal embayment rotation: Response to extreme events and climate control using full embayment surveys. Geomorphology, 327, 385-403.

Wiggins, M., Scott, T., Masselink, G., Russell, P., \& Valiente, N.G. (2019). Regionally-coherent Embayment Rotation: Behavioural Response to Bi-Directional Waves and Atmospheric Forcing. Journal of Marine Science and Engineering, 7, 116. 